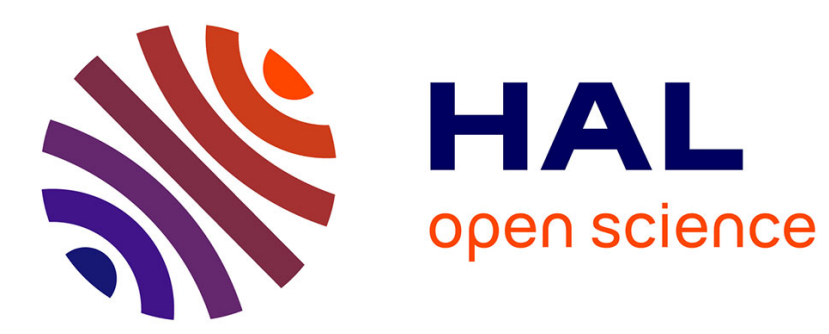

\title{
Kinetic modelling of phenols consumption during polyethylene thermal oxidation
}

\author{
Emmanuel Richaud
}

\section{To cite this version:}

Emmanuel Richaud. Kinetic modelling of phenols consumption during polyethylene thermal oxidation. European Polymer Journal, 2013, 49 (8), pp.2223-2232. 10.1016/j.eurpolymj.2013.04.027 . hal-00860174

\section{HAL Id: hal-00860174 https://hal.science/hal-00860174}

Submitted on 10 Sep 2013

HAL is a multi-disciplinary open access archive for the deposit and dissemination of scientific research documents, whether they are published or not. The documents may come from teaching and research institutions in France or abroad, or from public or private research centers.
L'archive ouverte pluridisciplinaire HAL, est destinée au dépôt et à la diffusion de documents scientifiques de niveau recherche, publiés ou non, émanant des établissements d'enseignement et de recherche français ou étrangers, des laboratoires publics ou privés. 


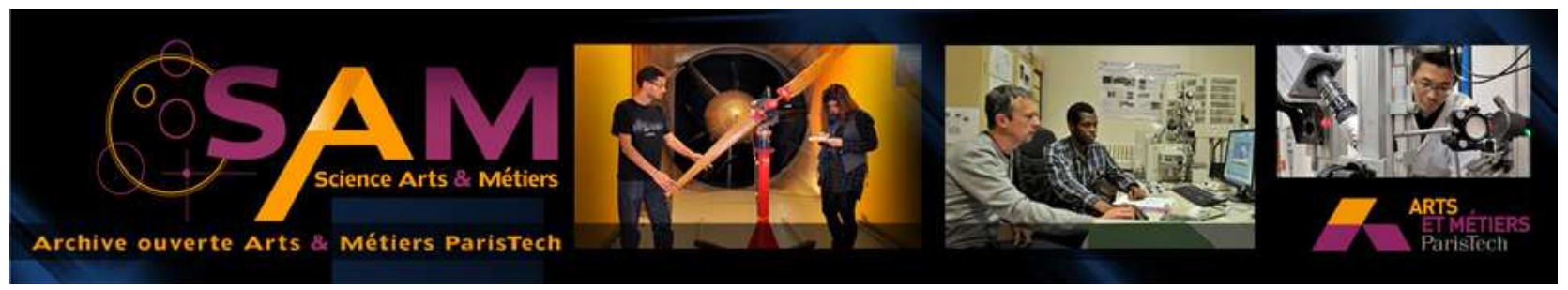

Science Arts \& Métiers (SAM)

is an open access repository that collects the work of Arts et Métiers ParisTech researchers and makes it freely available over the web where possible.

This is an author-deposited version published in: http://sam.ensam.eu Handle ID: .http://hdl.handle.net/10985/7295

\section{To cite this version :}

Emmanuel RICHAUD - Kinetic modelling of phenols consumption during polyethylene thermal oxidation - European Polymer Journal - Vol. 49, n8, p.2223-2232 - 2013 


\title{
KINETIC MODELLING OF PHENOLS CONSUMPTION DURING \\ POLYETHYLENE THERMAL OXIDATION
}

\author{
By Emmanuel RICHAUD* \\ Arts et Metiers ParisTech, CNRS, PIMM UMR 8006, 151 bd de l'Hôpital - 75013 PARIS - \\ France \\ * corresponding author: emmanuel.richaud@ensam.eu
}

\begin{abstract}
Irganox 1010 stabilized PE was monitored by carbonyl build-up and DSC under oxygen. A scheme for PE stabilization by phenols was implemented and its kinetic parameters were calculated from experimental results. This model was validated from its ability to simulate kinetics curves for carbonyl build up, induction period changes with stabilizer concentration, and stabilizer depletion curve in thermal ageing. The use of OIT measurement for quantifying stabilizer is also discussed. Kinetic analysis showed that OIT is actually proportional to stabilizer concentration in virgin samples but this is not true for aged samples because of negative influence of oxidation unstable by-products. The model was also employed for discussing some scenarii proposed as explanation of heterogeneity observed during thermal oxidation of stabilized polyolefins.
\end{abstract}

\section{KEYWORDS}

Polyethylene, thermal ageing, kinetic modelling, phenolic antioxidants, OIT 


\section{INTRODUCTION}

Many studies illustrate the effect of stabilizer on polymer ageing. Most of them compare stabilizers molecules by their ability to increase time to embrittlement, or carbonyl induction period [1]. Studying the rate of stabilizer depletion would permit to determine the phenomena involved in stabilizer disappearance (chemical consumption, physical loss ...) and further to improve the choice of stabilizer. For that purpose, two approaches can be envisaged:

- Analytical methods: spectroscopic, chromatographic or thermal detection of stabilizer and its by-products $[2,3]$. The measurement of Oxidation Induction Time by DSC under oxygen is one of most popular methods because of its simplicity $[4,5,6]$.

- Kinetics approach: proposal of a mechanistic scheme for stabilizer action, determination of kinetics parameters from experimental data and prediction of changes in antioxidant concentration.

Implementing the kinetic approach requires understanding the stabilizer physico-chemistry, which is very complex [7]:

(1) Stabilizer can be consumed by chemical reaction or lost by evaporation or extraction [8].

(2) Stabilizer is partially soluble $[9,10,11,12]$. In previous papers $[13,14]$, we successfully simulated the behavior of phosphites and sulfurs by supposing that stabilizer soluble part disappear by reaction and evaporation, and insoluble one works as a reservoir maintaining the amorphous phase at the saturation limit as long as it is not totally consumed:

(3) In thick samples, its efficiency depends on its rate of diffusion from the bulk to the surface. 
The physical parameters (rate of evaporation $\mathrm{H}$, solubility limit $[\mathrm{Stab}]_{\mathrm{sat}}$, or diffusivity D...) can be estimated for each polymer-stabilizer mixture:

- D value for several antioxidants in polyolefins are available in several papers $[15,16,17,18]$, and can be predicted by some models linking D with temperature and stabilizer molar mass [19].

- Values of parameter $\mathrm{H}$ for evaporation rate values are also given in literature [20]. Their value may be estimated from kinetics of stabilizer loss under nitrogen [14].

- Estimation of solubility limit of stabilizers (being relatively polar molecules) in polyolefins from a theoretical approach is relatively complex: as observed for example by Billingham [9,14], regular solution theory (which is derived from Flory Huggins approach) is shown to give a good basis for extrapolation of data but cannot predict solubilities. This is not surprising first because approach derived from Flory's theory cannot be when polar interactions exist between polymer and stabilizer, and also because of the semi-crystalline nature of polyolefins [21]. Hence, the solubility of a stabilizer in a polyolefin can only be estimated from reported experimental values together with some structure properties relationships [22].

It remains to estimate the kinetic constants for stabilizer chemical consumption. In the case of 2,6 di-tert-butylphenols, it was shown that the efficiency per phenol group does not differ strongly from a family member to another [23]. Rate constants of stabilization were thus calculated from a literature review of degradation of several PP + phenol mixtures. Their physical sense constituted a partial validation which needs to be confirmed regarding other criteria. 
In this paper, we will try to complete this previous investigation by implementing the following approach:

1. Estimation stabilization constants from experimental data in the case of PE + Irganox 1010 chosen here as a model phenolic antioxidant (presumably non volatile and soluble enough for neglecting in a first approach physical effects of stabilisation and simplify the modelling).

2. Discuss on the ability of the model to simulate the shape of stabilizer residual concentration curve. We already obtained promising results in comparable studies for hydroperoxides decomposers $[13,14]$ but it was in case of a major volatile loss so that it is not sure that the stabilizer depletion only due to chemical reaction is accurately simulated. Since Oxidation Induction Time measurement (by Chemiluminescence or DSC) is a commonly employed [46], we will try to discuss on the reliability of this method for determining the residual quantity of stabilizer in polymer after exposure.

3. Several papers report that oxidation of stabilized polymer is heterogeneous $[24,25]$, due to local presence of impurities or inhomogeneous stabilizer repartition. The model will be here used as a comprehensive tool for testing the proposed scenario in literature. 


\section{EXPERIMENTAL}

\section{Materials}

The PE powder (supplied by Borealis) was stabilizer free, as confirmed by the absence of any induction period in the control DSC isothermal thermograms at $200^{\circ} \mathrm{C}$. Compounded samples were prepared by pouring a solution of Irganox 1010 (CAS 98584-37-3) in dichloromethane onto the PE powder. The stabilizer concentration and the solution volume were adjusted in order to obtain the desired stabilizer concentration in the PE. After solvent evaporation at room temperature, thick films, about $100 \mu \mathrm{m}$, were compression moulded at $200^{\circ} \mathrm{C}$ under 240 MPa pressure for $30 \mathrm{~s}$ using a laboratory press (Gibrite Instrument).

The initial stabilizer concentration in the PE amorphous phase was calculated using:

$$
[\mathrm{AH}]=\frac{1}{1-\mathrm{x}_{\mathrm{C}}} \cdot \frac{\rho_{\mathrm{PE}}}{\mathrm{M}_{\mathrm{Stab}}} \cdot \mathrm{x}_{\mathrm{Stab}} \cdot \mathrm{f}_{\mathrm{Stab}}
$$

Where:

$-\mathrm{x}_{\mathrm{C}}$ is the crystallinity ratio taken as equal to 0 in molten state and 0.5 in solid state,

- $\rho_{\mathrm{PE}}$ is the polymer density $\left(935 \mathrm{~g} \mathrm{l}^{-1}\right)$,

- $\mathrm{M}_{\text {Stab }}$ is the stabilizer molar mass $\left(\mathrm{g} \mathrm{mol}^{-1}\right)$,

$-\mathrm{X}_{\text {Stab }}$ is the global stabilizer weight ratio in the polymer,

- $\mathrm{f}_{\mathrm{Stab}}$ is the stabilizer functionality, i.e. the number of active groups per molecule (4 for Irganox 1010).

\section{Characterization}




\subsection{Infra Red spectrophotometry}

FTIR spectra of the PE films were recorded in transmittance mode using a Bruker IFS 28 spectrophotometer by averaging 32 scans at $4 \mathrm{~cm}^{-1}$ resolution. The absorbance of carbonyl compounds resulting from PE oxidation were converted into concentration using the molar absortivity of $3001 \mathrm{~mol}^{-1} \mathrm{~cm}^{-1}$ for the peak at $1715 \mathrm{~cm}^{-1}[26]$.

\subsection{Determination of the stabilizer concentration using OIT measurements}

Samples were analysed using the standard DSC under oxygen (OIT) at $200^{\circ} \mathrm{C}$ using a Q10 apparatus (TA Instruments). OIT temperature measurement triggers:

- Sensitivity, with the detection of the onset [27],

- Analysis time [27],

- Additive volatilization, as observed by comparing OIT values for PE + Irganox 1010 or PE + Irganox 1076 at $190^{\circ} \mathrm{C}$ for instance [14].

Here, $\mathrm{T}=200^{\circ} \mathrm{C}$ was chosen a good compromise.

The polymer samples (systematically ca $5 \mathrm{mg}$ giving a ca $100 \mu \mathrm{m}$ sample thickness expected to minimize the DLO effect) were first heated under nitrogen to $200^{\circ} \mathrm{C}$ followed by a $5 \mathrm{~min}$ isothermal segment before switching to oxygen and then monitoring the time to the exotherm (denoted by $\mathrm{OIT}_{200}$ ). This measure is currently used for determining both initial and residual stabilizer activities and its limits will be discussed in the present paper. Fig. 1 depicts the shape of isothermal segment under oxygen for pristine samples of PE with and without stabilizer. 


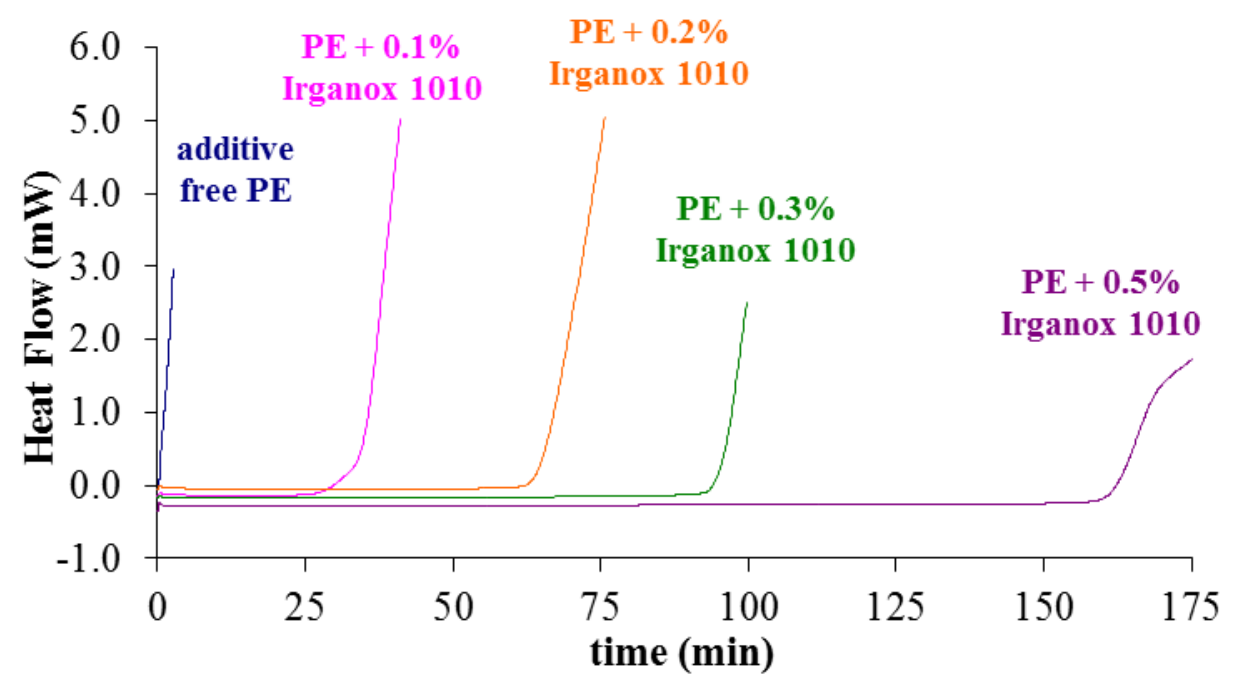

Figure 1. Isothermal part of DSC thermogram at $200^{\circ} \mathrm{C}$ under $0.1 \mathrm{MPa}_{2}$ for $\mathrm{PE}+\mathrm{Irganox}$ 1010.

\section{Thermal ageing}

Ageing of polyethylene films was carried out in air at $110^{\circ} \mathrm{C}$ and $120^{\circ} \mathrm{C}$ in ventilated ovens. 


\section{RESULTS}

\section{Oxidation at molten state}

DSC-OIT curves for PE with several amounts of Irganox 1010 are given in Fig. 1. They call for the following comments:

(1) Identically to what is very well documented in literature, OIT increases here linearly with stabilizer amount [27,28,29,30,31,32,33,34,35,36,37].

(2) It is not easy to determine from the shape of such oxidation curves if antioxidant disappears because of chemical consumption (reactions with $\mathrm{POO}^{\circ}, \mathrm{POOH} .$. ) or physical loss (evaporation for example). According to previous investigations [13,14], we have proposed to analyse the change of induction period with the nominal stabilizer concentration:

- In case of reaction coupled with evaporation + partial demixion, the stabilizer excess (compared to solubility limit) rather evaporates and its effect on induction period enhancement is almost negligible. The "induction period vs stabilizer concentration" curve displays hence a hyperbolic shape.

- In a case of reaction as major source of stabilizer consumption, the "induction period vs stabilizer concentration" curve turns to be almost linear.

These observations militate in favour of neglecting the evaporation here, in good agreement with other observations reported in the following of this section from monitoring the residual concentration of Irganox 1010 ester group.

(3) It can be observed that PE $+0.5 \%$ Irganox 1010 sample shows a second slow oxidation step (a sort of retardation process) in contrast with one step fast oxidation step for PE +0.1 - 
$0.3 \%$ Irganox $1010 \%$. The possible role of phenolic antioxidant by products at high Irganox 1010 concentration may be evoked as an explanation [38]. In the following, we will focus on induction period (previously observed as being the crucial parameter for describing phenol efficiency [23]) rather than on the higher conversion degrees. Anyway, the model proposed here will have undoubtedly to be completed in the future to describe the degradation at high conversion degrees or involving the role of secondary stabilizer by-products.

\section{Oxidation at solid state}

Experimental results for carbonyl build-up and residual value of OIT at $200^{\circ} \mathrm{C}$ for oxidation at $110^{\circ} \mathrm{C}$ and $120^{\circ} \mathrm{C}$ are presented in Fig. 2 and Fig. 3:

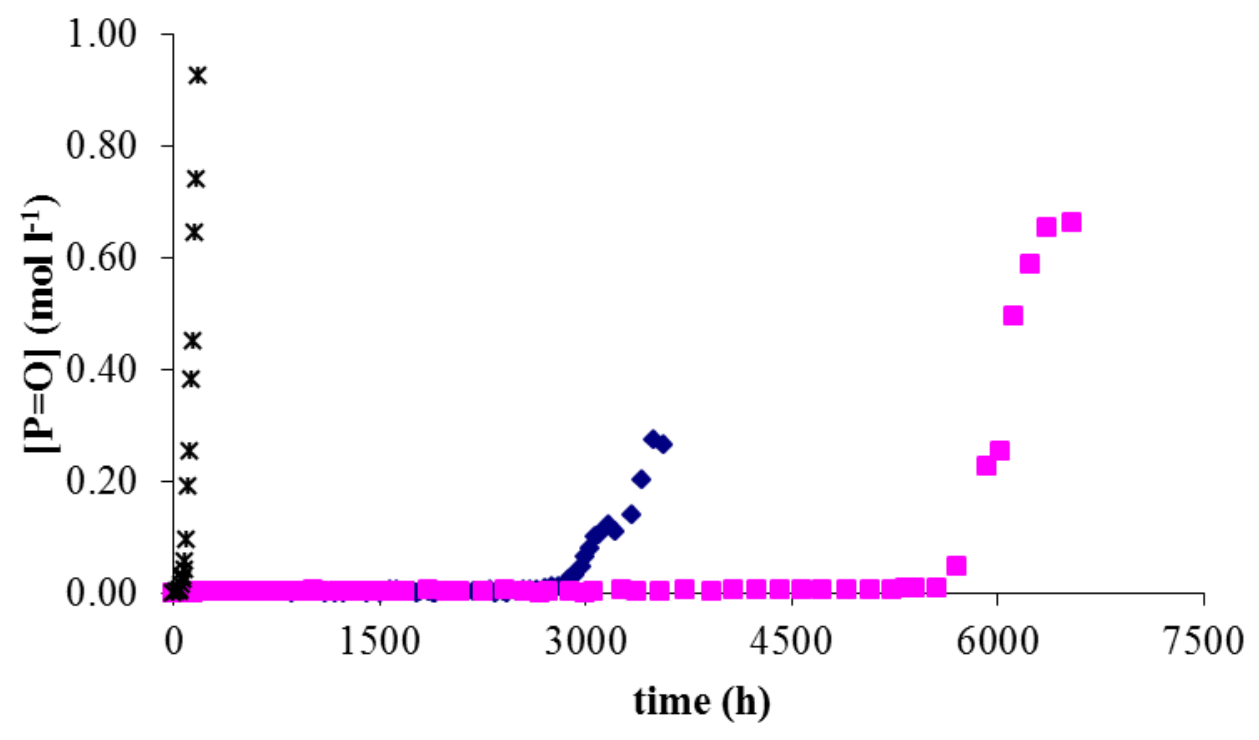

(a) 


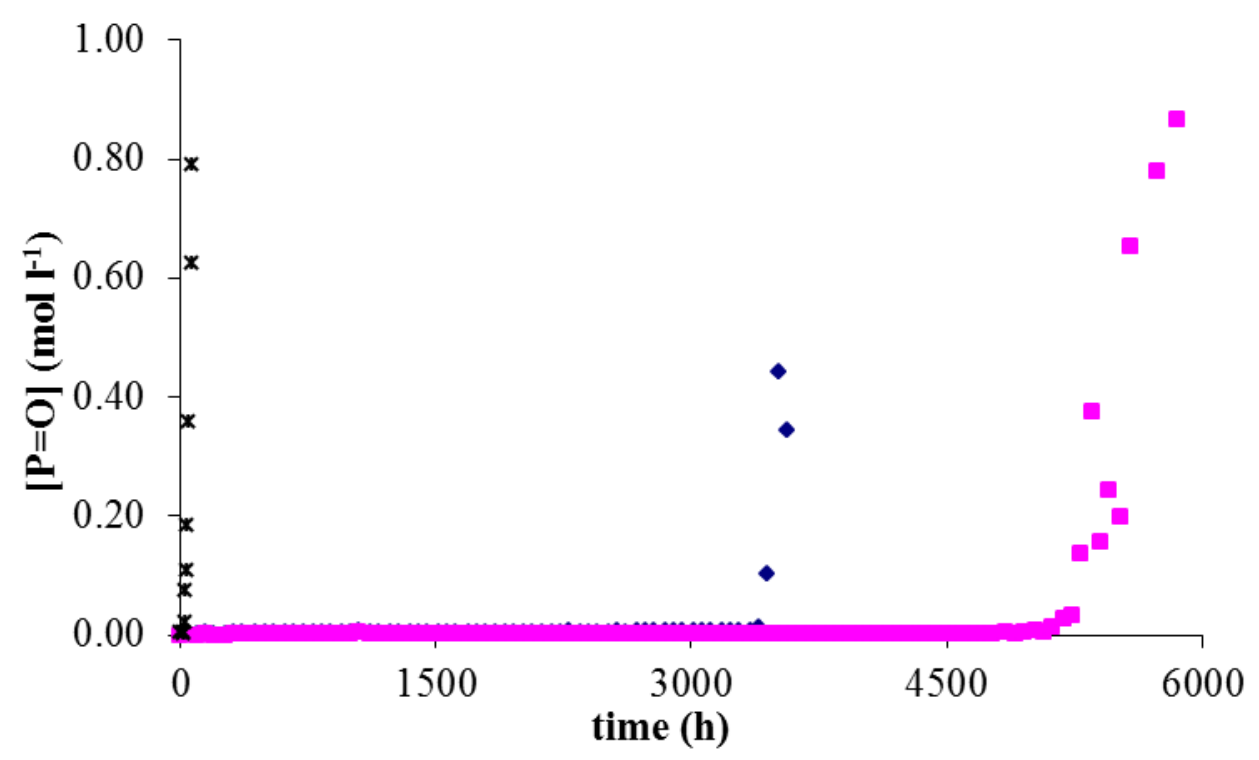

(b)

Figure 2. Kinetic curves for carbonyl build-up air for pure PE (*), PE + 0.1\% Irganox 1010 $(\diamond)$ and PE $+0.2 \%$ Irganox $1010(\square)$ thermally oxidized under air at $110^{\circ} \mathrm{C}$ (a) and $120^{\circ} \mathrm{C}$ (b).

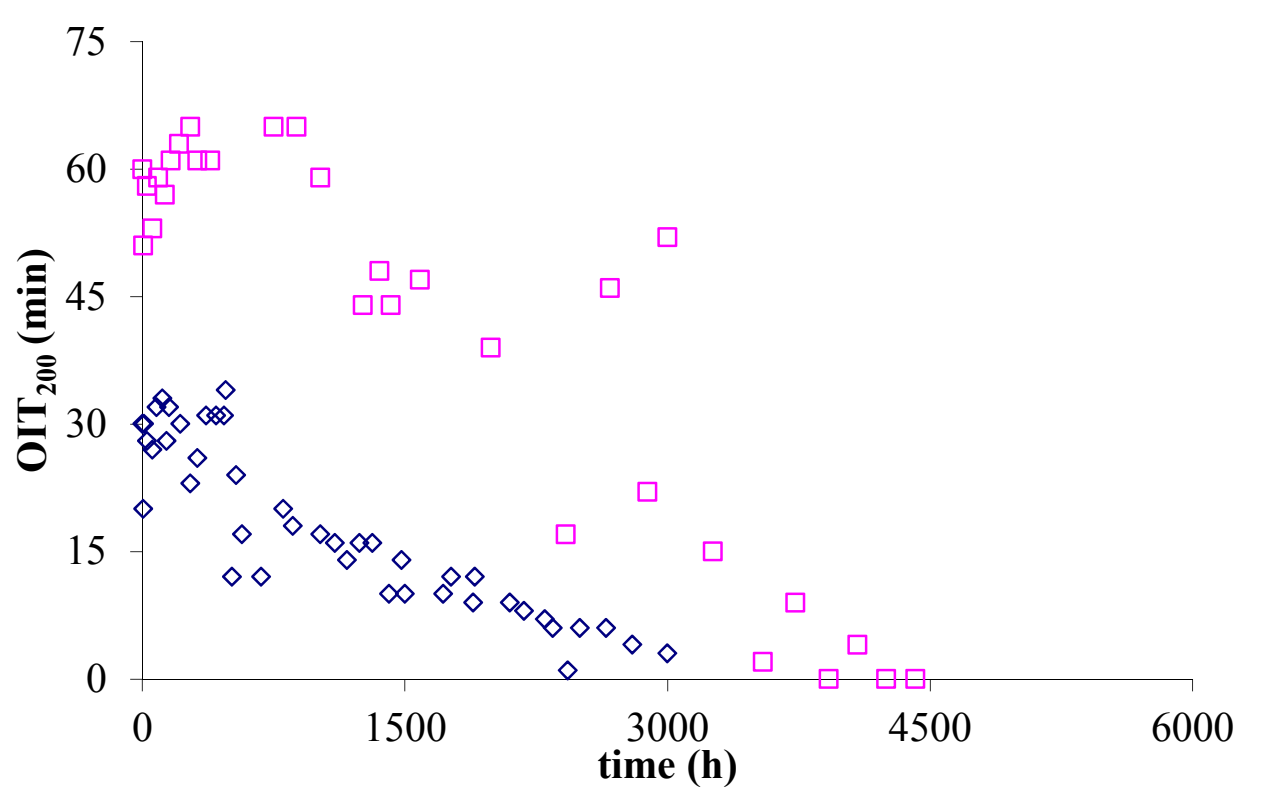

(a) 


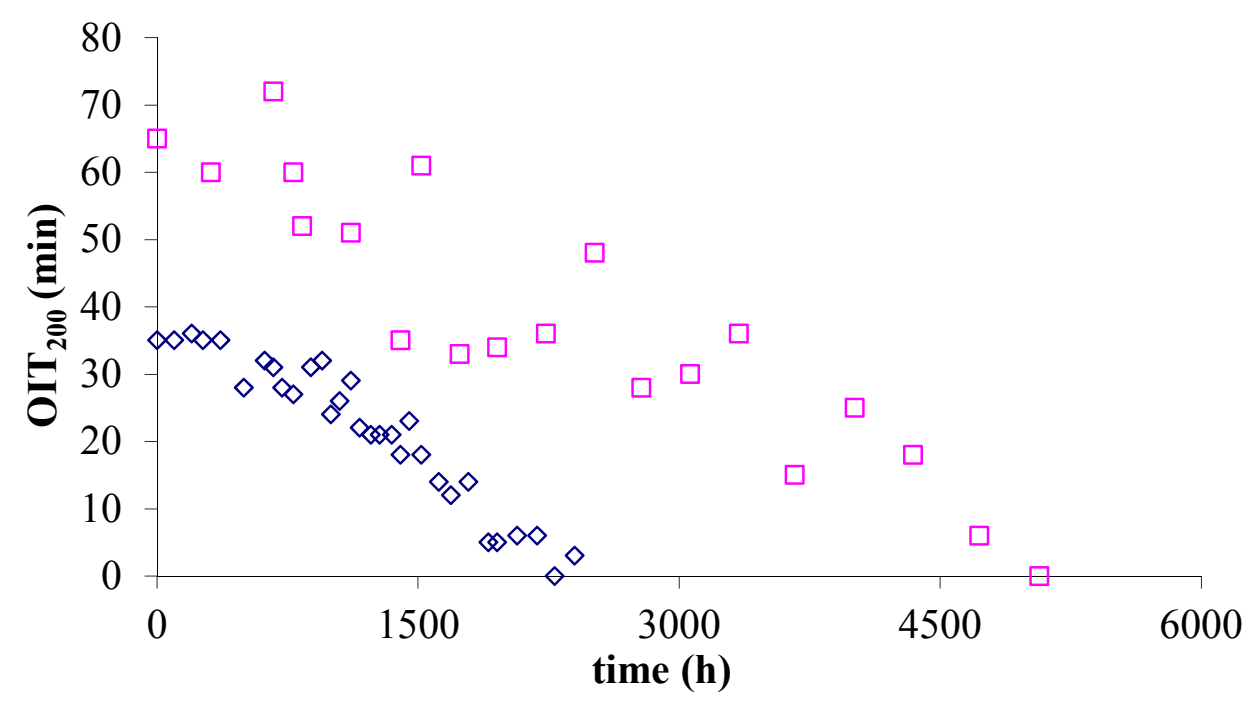

(b)

Figure 3. Experimental values of residual $\mathrm{OIT}$ at $200^{\circ} \mathrm{C}$ of $\mathrm{PE}+0.1 \% \operatorname{Irganox} 1010(\diamond), \mathrm{PE}$ $+0.2 \%$ Irganox $1010(\square)$ for thermal oxidation under air at $110^{\circ} \mathrm{C}(\mathrm{a})$ and $120^{\circ} \mathrm{C}(\mathrm{b})$.

Kinetic curves for carbonyl build-up display the classical quasi-sigmoidal shape. The changes of maximal oxidation rate with the initial stabilizer concentration are significantly lower in case of phenolic antioxidant (for example in PP [23], squalane [39] or cumene [40] consistently with the fact that phenols behave as sacrificial stabilizers i.e. that induction period ends when all stabilizing species are totally consumed) than in the case of HAS where stabilizing by-products remain efficient even after the end of induction period [41] which induces a decrease of maximal oxidation rate when increasing the HAS concentration $[39,42]$.

$\mathrm{OIT}_{200}$ is related to the residual concentration of unreacted phenol. It decreases obeying an apparent zero order law as also observed in $[43,44,45,46]$, which will be discussed later. Pseudo first-order curves are also reported in literature [47] but this difference could come from the complexity of studied materials $(\mathrm{PE}+$ phenol thin films here instead of phenol + phosphite thick samples elsewhere). 
$1745 \mathrm{~cm}^{-1}$ absorbance decrease is explained by ester loss group ascribed to physical loss process by evaporation [13]. This process was considered as negligible in the studied timescale even at $120^{\circ} \mathrm{C}$ (Fig. 4). This conclusion can be drawn to each case where induction period duration increases linearly with initial stabilizer concentration [14]. Therefore, phenol depletion will be only considered as caused by chemical consumption in the following.

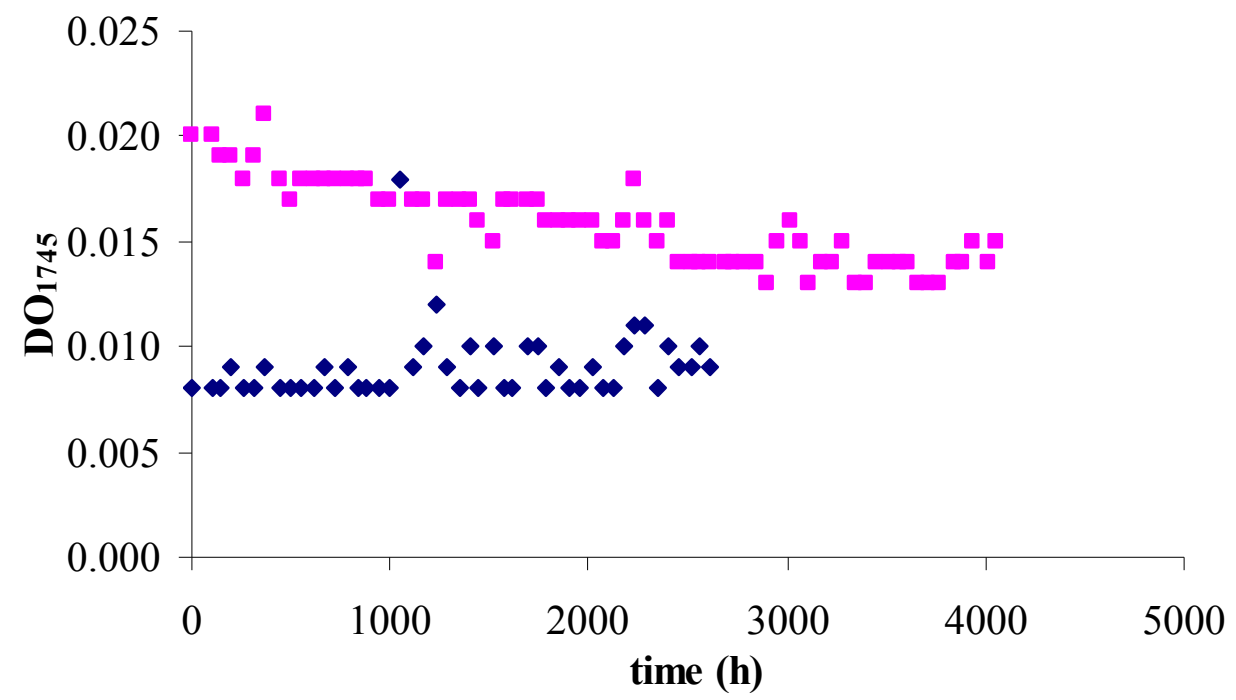

Figure 4. Absorbance of Irganox 1010 ester group at $1745 \mathrm{~cm}^{-1}$ for PE $+0.1 \%$ Irganox 1010 $(\diamond)$ and PE $+0.2 \%$ Irganox $1010(\square)$ thermally oxidized under air at $120^{\circ} \mathrm{C}$. 


\section{DISCUSSION}

\section{Proposal of a kinetic modelling for $\mathbf{P E}+$ phenols}

Mechanisms of stabilization by hindered phenols are reviewed elsewhere $[48,49,50]$. Despite the reported mechanistic complexity, the following stabilization scheme:

$$
\begin{array}{ll}
\mathrm{AH}+\mathrm{POO}^{\circ} \rightarrow \mathrm{A}^{\circ}+\mathrm{POOH} & \mathrm{k}_{\mathrm{S} 1} \\
\mathrm{~A}^{\circ}+\mathrm{POO}^{\circ} \rightarrow \mathrm{POO}-\mathrm{A} & \mathrm{k}_{\mathrm{S} 2}
\end{array}
$$

can be used on the assumption that it is realistic enough with a limited number of adjustable parameters [23]. The model for PE + phenols thermal oxidation is thus made from pure PE scheme (Table 1) completed with $\mathrm{S} 1$ and $\mathrm{S} 2$ reaction.

\begin{tabular}{|c|c|c|c|c|}
\hline Code & Reaction & $\begin{array}{c}\text { Rate } \\
\text { constant }\end{array}$ & Values at 110 & Activation energies \\
\hline $1 \mathrm{u}$ & $\mathrm{POOH} \rightarrow 2 \mathrm{P}^{\circ}+\gamma_{\mathrm{CO}} \mathrm{PC}=\mathrm{O}+\gamma_{\mathrm{S}} \mathrm{C}$ & $\mathrm{k}_{1 \mathrm{u}}$ & $6.6 \times 10^{-7} \mathrm{~s}^{-1}$ & $140 \mathrm{~kJ} \mathrm{~mol}^{-1}$ \\
$1 \mathrm{~b}$ & $\mathrm{POOH}+\mathrm{POOH} \rightarrow \mathrm{P}^{\circ}+\mathrm{POO}^{\circ}+\gamma_{\mathrm{CO}} \mathrm{PC}=\mathrm{O}+\gamma_{\mathrm{S}} \mathrm{s}$ & $\mathrm{k}_{1 \mathrm{~b}}$ & $1.3 \times 10^{-5} 1 \mathrm{~mol}^{-1} \mathrm{~s}^{-1}$ & $105 \mathrm{~kJ} \mathrm{~mol}^{-1}$ \\
2 & $\mathrm{P}^{\circ}+\mathrm{O}_{2} \rightarrow \mathrm{POO}^{\circ}$ & $\mathrm{k}_{2}$ & $1.0 \times 10^{8} 1 \mathrm{~mol}^{-1} \mathrm{~s}^{-1}$ & $0 \mathrm{~kJ} \mathrm{~mol}^{-1}$ \\
3 & $\mathrm{kOO}_{3}+\mathrm{PH} \rightarrow \mathrm{POOH}+\mathrm{P}^{\circ}$ & $1.71 \mathrm{~mol}^{-1} \mathrm{~s}^{-1}$ & $73 \mathrm{~kJ} \mathrm{~mol}^{-1}$ \\
4 & $\mathrm{k}_{4}$ & $8.0 \times 10^{11} 1 \mathrm{~mol}^{-1} \mathrm{~s}^{-1}$ & $0 \mathrm{~kJ} \mathrm{~mol}^{-1}$ \\
5 & $\mathrm{P}^{\circ}+\mathrm{P}^{\circ} \rightarrow$ inactive products & $\mathrm{k}_{5}$ & $2.3 \times 10^{11} 1 \mathrm{~mol}^{-1} \mathrm{~s}^{-1}$ & $0 \mathrm{~kJ} \mathrm{~mol}^{-1}$ \\
60 & $\mathrm{POO}^{\circ}+\mathrm{POO}^{\circ} \rightarrow\left[\mathrm{PO}{ }^{\circ} \mathrm{OP}\right]_{\mathrm{cage}}+\mathrm{O}_{2}$ & $\mathrm{k}_{60}$ & $6.1 \times 10^{8} 1 \mathrm{~mol}^{-1} \mathrm{~s}^{-1}$ & $80 \mathrm{~kJ} \mathrm{~mol}^{-1}$ \\
61 & {$\left[\mathrm{PO}^{\circ}+{ }^{\circ} \mathrm{OP}\right]_{\mathrm{cage}} \rightarrow \mathrm{POOP}$} & $\mathrm{k}_{61}$ & $2.0 \times 10^{6} \mathrm{~s}^{-1}$ & $0 \mathrm{~kJ} \mathrm{~mol}^{-1}$ \\
62 & {$\left[\mathrm{PO}^{\circ}+{ }^{\circ} \mathrm{OP}\right]_{\mathrm{cage}} \rightarrow \mathrm{POH}+\mathrm{PC}=\mathrm{O}$} & $\mathrm{k}_{62}$ & $2.4 \times 10^{5} \mathrm{~s}^{-1}$ & $5 \mathrm{~kJ} \mathrm{~mol}^{-1}$ \\
63 & {$\left[\mathrm{PO}^{\circ}+{ }^{\circ} \mathrm{OP}\right]_{\mathrm{cage}} \rightarrow 2 \mathrm{P}^{\circ}+2 \gamma_{\mathrm{CO}} \mathrm{PC}=\mathrm{O}+2 \gamma_{\mathrm{S}} \mathrm{S}$} & $\mathrm{k}_{63}$ & $1.2 \times 10^{6} \mathrm{~s}^{-1}$ & $50 \mathrm{~kJ} \mathrm{~mol}^{-1}$ \\
\hline
\end{tabular}

Table 1. Kinetic parameters of pure PE oxidation model [51].

Rates constants for pure PE (reactions $1 \mathrm{u} . .63$ ) were previously determined [50] and will be used here without any changes. It is here tried to simulate degradation curves of stabilized polymers using 3 supplementary parameters: $[\mathrm{AH}]_{0}, \mathrm{k}_{\mathrm{S} 1}$ and $\mathrm{k}_{\mathrm{S} 2}\left([\mathrm{AH}]_{0}\right.$ comes from Eq. 1 and 
is not here an adjustable parameter). It is possible to simulate an increase in induction period together with keeping a constant maximal oxidation rate using an infinity of $\left(\mathrm{k}_{\mathrm{S} 1}, \mathrm{k}_{\mathrm{S} 2}\right)$ set. Our strategy is thus to fix $\mathrm{k}_{\mathrm{S} 2}$, this parameter having a weak influence on simulations provided its value exceeds $10^{5} 1 \mathrm{~mol}^{-1} \mathrm{~s}^{-1}$ which is the expected order of magnitude for a termination process involving a very reactive $\left(\mathrm{P}^{\circ}\right)$ and a moderately one $\left(\mathrm{A}^{\circ}\right)$ radical [23]. Here, $\mathrm{k}_{\mathrm{S} 2}=$ $5.10^{8} 1 \mathrm{~mol}^{-1} \mathrm{~s}^{-1}$ will be used whatever the temperature as suggested by data compiled by Denisov for PE [52] (Table 2).

\begin{tabular}{|c|c|c|c|c|c|c|}
\hline para substituant & $\mathrm{OMe}$ & $\mathrm{Ph}$ & $\mathrm{CMe}_{3}$ & $\mathrm{CN}$ & $\mathrm{CO}-\mathrm{Ph}$ & $\mathrm{Cl}$ \\
\hline $\mathbf{k}_{\mathbf{s} \mathbf{2}} \times \mathbf{1 0}^{-\mathbf{8}}\left(\mathbf{I ~ m o l}^{\mathbf{- 1}} \mathbf{s}^{\mathbf{- 1}} \mathbf{)}\right.$ & 7.2 & 6 & 3.2 & 2.7 & 1.9 & 1.7 \\
\hline
\end{tabular}

Table 2. Kinetic constants for (S2) reaction [51].

$\mathrm{k}_{\mathrm{S} 1}$ is thus the only adjustable parameter. Its value will be tentatively determined from fitting experimental results (the so-called inverse approach) [23].

In the case of PE oxidation in solid state, thickness of oxidized layers was reported to be ca 1 $\mathrm{mm}$ [53]. In the case of OIT measurements, sample mass is often on the order of $5 \mathrm{mg}$ i.e. that thickness of molten sample in the DSC pan is ca $100 \mu \mathrm{m}$. In other words, the fickian term relative to diffusion-reaction coupling for mobile species (phenols, oxygen) can be neglected.

Basing on the model reactions proposed in Table 1 and the proposed stabilization scheme, the following set of differential equations is derived:

$$
\frac{\mathrm{d}\left[\mathrm{P}^{\circ}\right]}{\mathrm{dt}}=2 \mathrm{k}_{1 \mathrm{u}}[\mathrm{POOH}]+\mathrm{k}_{1 \mathrm{~b}}[\mathrm{POOH}]^{2}-\mathrm{k}_{2}\left[\mathrm{P}^{\circ}\right]\left[\mathrm{O}_{2}\right]+\mathrm{k}_{3}\left[\mathrm{POO}^{\circ}\right][\mathrm{PH}]+2 \mathrm{k}_{63}\left[\mathrm{PO}^{\circ \circ} \mathrm{OP}\right]_{\text {cage }}
$$




$$
\begin{array}{r}
\frac{\mathrm{d}\left[\mathrm{POO}^{\circ}\right]}{\mathrm{dt}}=\mathrm{k}_{1 \mathrm{~b}}[\mathrm{POOH}]^{2}+\mathrm{k}_{2}\left[\mathrm{P}^{\circ}\right]\left[\mathrm{O}_{2}\right]-\mathrm{k}_{3}\left[\mathrm{POO}^{\circ}\right][\mathrm{PH}]-2 \mathrm{k}_{60}\left[\mathrm{POO}^{\circ}\right]^{2} \\
-\mathrm{k}_{\mathrm{S} 1}\left[\mathrm{POO}^{\circ}\right][\mathrm{AH}]-\mathrm{k}_{\mathrm{S} 2}\left[\mathrm{POO}^{\circ}\right]\left[\mathrm{A}^{\circ}\right]
\end{array}
$$

$\frac{\mathrm{d}[\mathrm{POOH}]}{\mathrm{dt}}=-\mathrm{k}_{1 \mathrm{u}}[\mathrm{POOH}]-2 \mathrm{k}_{1 \mathrm{~b}}[\mathrm{POOH}]^{2}+\mathrm{k}_{3}\left[\mathrm{POO}^{\circ}\right][\mathrm{PH}]+\mathrm{k}_{\mathrm{S} 1}\left[\mathrm{POO}^{\circ}\right][\mathrm{AH}]$

$\frac{\mathrm{d}\left[\mathrm{PO}^{\circ} \mathrm{OP}\right]_{\text {cage }}}{\mathrm{dt}}=\mathrm{k}_{60}\left[\mathrm{POO}^{\circ}\right]^{2}-\left(\mathrm{k}_{61}+\mathrm{k}_{62}+\mathrm{k}_{63}\right)\left[\mathrm{PO}^{\circ \circ} \mathrm{OP}\right]_{\text {cage }}$

$\frac{\partial\left[\mathrm{O}_{2}\right]}{\partial \mathrm{t}}=\mathrm{k}_{60}\left[\mathrm{POO}^{\circ}\right]^{2}-\mathrm{k}_{2}\left[\mathrm{P}^{\circ}\right]\left[\mathrm{O}_{2}\right]$

$\frac{\partial[\mathrm{AH}]}{\partial \mathrm{t}}=-\mathrm{k}_{\mathrm{S} 1}\left[\mathrm{POO}^{\circ}\right][\mathrm{AH}]$

$\frac{\mathrm{d}\left[\mathrm{A}^{\circ}\right]}{\mathrm{dt}}=\mathrm{k}_{\mathrm{S} 1}\left[\mathrm{POO}^{\circ}\right][\mathrm{AH}]-\mathrm{k}_{\mathrm{S} 2}\left[\mathrm{POO}^{\circ}\right]\left[\mathrm{A}^{\circ}\right]$

The system was solved with the following boundaries conditions, some of them $\left(\left[\mathrm{P}^{\circ}\right]_{0}\right.$, $\left.\left[\mathrm{POO}^{\circ}\right]_{0},[\mathrm{POOH}]_{0}\right)$ being already used for PE $[13,41,54]$ and tentatively justified in another study [55]:

at $=0$ :

$\left[\mathrm{P}^{\circ}\right]=\left[\mathrm{POO}^{\circ}\right]=\left[\mathrm{PO}^{\circ \circ} \mathrm{OP}\right]_{\mathrm{cage}}=0$

$[\mathrm{POOH}]_{0}=10^{-4} \mathrm{~mol} \mathrm{l}^{-1}$

$[\mathrm{PH}]$ is the concentration in abstractable hydrogens calculated as:

$[\mathrm{PH}]=2 \times$ number of mole of ethylene/volume of polymer

$$
=\frac{2 \text { Xvolumis mass of golyathylena }}{\text { molar mass of ethylene unlt }} \sim 60 \mathrm{~mol} \mathrm{l}^{-1}
$$

$\left[\mathrm{O}_{2}\right]=\mathrm{s}_{\mathrm{O} 2} \times \mathrm{P}_{\mathrm{O} 2}, \mathrm{P}_{\mathrm{O} 2}$ being the partial oxygen pressure and $\mathrm{s}_{\mathrm{O} 2}$ the oxygen

solubility in amorphous phase of $\mathrm{PE}: \mathrm{s}_{\mathrm{O} 2}=1.8 \times 10^{-8} \mathrm{~mol}^{-1} \mathrm{~Pa}^{-1}[56]$.

$[\mathrm{AH}]_{0}$ is given by Eq. 1

$\left[\mathrm{A}^{\circ}\right]_{0}=0$ 
The solution of the differential system obtained by numerical way (ODE23s solver of Matlab software) is the concentration in reactive species $\mathrm{P}^{\circ}, \mathrm{POO}^{\circ}, \mathrm{POOH},\left[\mathrm{PO}{ }^{\circ} \mathrm{OP}\right]_{\text {cage }}, \mathrm{AH}, \mathrm{A}^{\circ}$ from which the changes in polymer chemistry can be simulated.

Let's start by degradation at PE molten state. We tentatively simulated the degradation course at $200^{\circ} \mathrm{C}$ by the changes of $\mathrm{POOH}$ concentration, having in mind that the exothermal signal measured in DSC is linked to the POOH concentration [57]. As it can be seen in Fig. 5, the simulation runs display actually several common features with experimental results reported in Fig. 1 (linear increase of induction period with stabilizer concentration together with a constant maximal degradation rate). $\mathrm{k}_{\mathrm{S} 1}$ was estimated ca $6 \times 10^{6} 1 \mathrm{~mol}^{-1} \mathrm{~s}^{-1}$ at $200^{\circ} \mathrm{C}$, on the assumption that there is no physical loss of Irganox 1010 at this temperature.

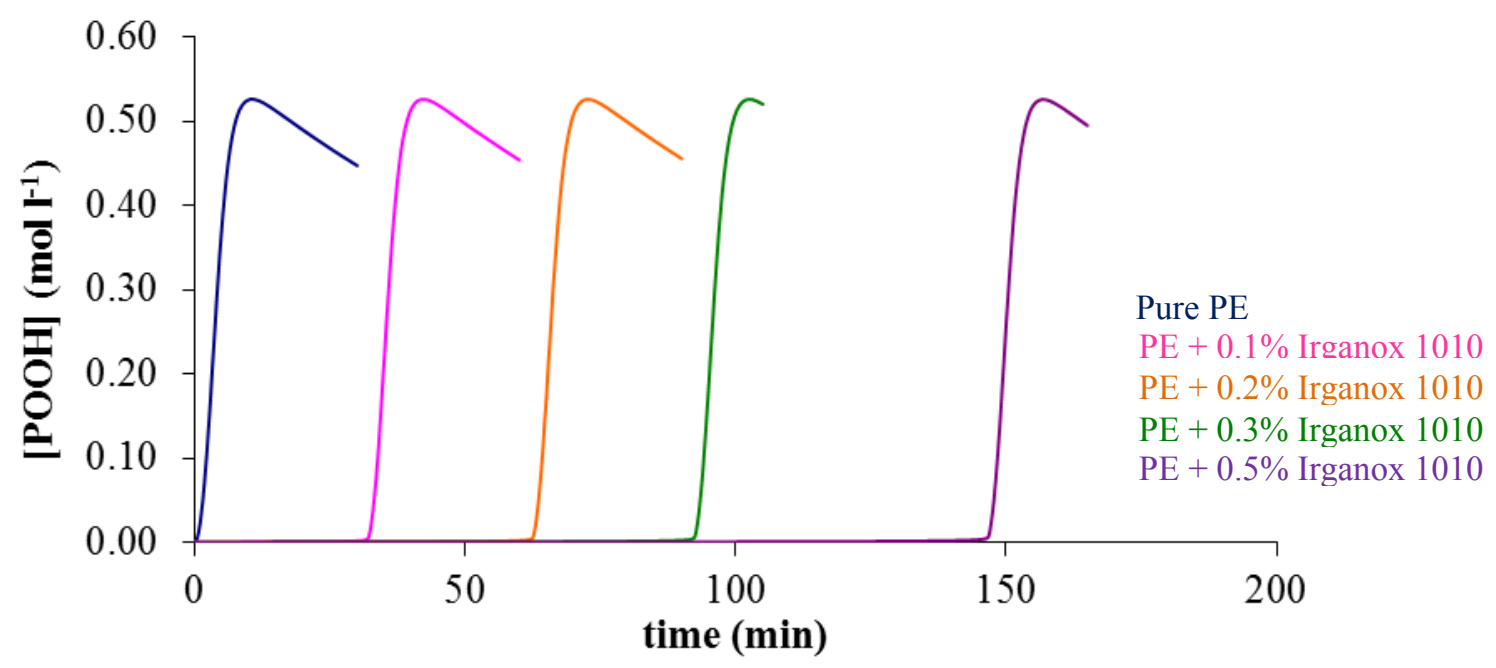

Figure 5. Simulation of oxidation curves for PE $+\operatorname{Irganox} 1010$ at $200^{\circ} \mathrm{C}$ under $0.1 \mathrm{MPa}$ for mimicking OIT measurements with $\mathrm{k}_{\mathrm{S} 1}=6 \times 10^{6} 1 \mathrm{~mol}^{-1} \mathrm{~s}^{-1}$.

Using other oxidation curves recorded by DSC-OIT or CL-OIT published in literature for PE + Irganox $1010[34,58,59], \mathrm{k}_{\mathrm{S} 1}$ was also estimated at 210,180 and $170^{\circ} \mathrm{C}$. 
Let us now turn to PE "solid state" oxidation, which was monitored by FTIR. Carbonyl buildup is calculated by post treating the solution of the model:

$$
\frac{\mathrm{d}[\mathrm{CO}]}{\mathrm{dt}}=\gamma_{\mathrm{CO}} \cdot\left(1-\mathrm{x}_{\mathrm{C}}\right) \cdot\left(\mathrm{k}_{1 \mathrm{u}}[\mathrm{POOH}]+\mathrm{k}_{1 \mathrm{~b}}[\mathrm{POOH}]^{2}+2 \cdot \mathrm{k}_{63}\left[\mathrm{PO}{ }^{\circ} \mathrm{OP}\right]_{\text {cage }}\right)
$$

where $\gamma_{\mathrm{CO}}$ is the carbonyl yield from $\mathrm{POOH}$ decomposition [51] and the $1-\mathrm{x}_{\mathrm{C}}$ term in Eq. 1 and 9 accounts for the semi-crystalline morphology (crystalline phase is here considered as an inert media, since neither oxygen nor antioxidants are soluble in PE crystals). $\mathrm{k}_{\mathrm{S} 1}$ is thus determined from fitting the carbonyl build up curves (an example of parametric study is presented in [23]). It is found:

$\mathrm{k}_{\mathrm{S} 1}=4 \times 10^{4} 1 \mathrm{~mol}^{-1} \mathrm{~s}^{-1}$ at $110^{\circ} \mathrm{C}$

$\mathrm{k}_{\mathrm{S} 1}=3 \times 10^{5} 1 \mathrm{~mol}^{-1} \mathrm{~s}^{-1}$ at $120^{\circ} \mathrm{C}$

The comparisons between modelling and experimental data are shown in Fig. 6 . 


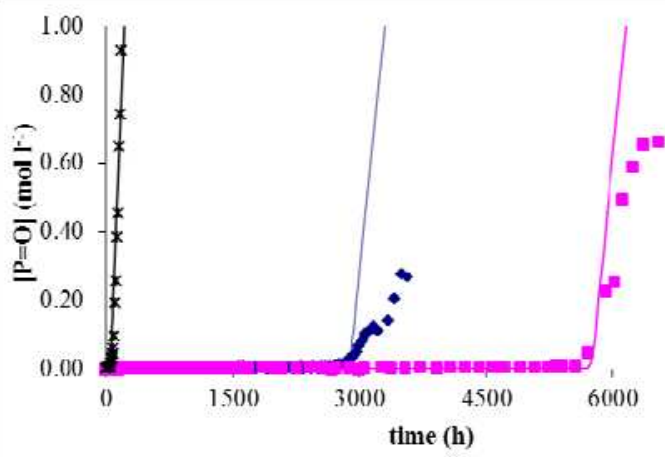

(a)

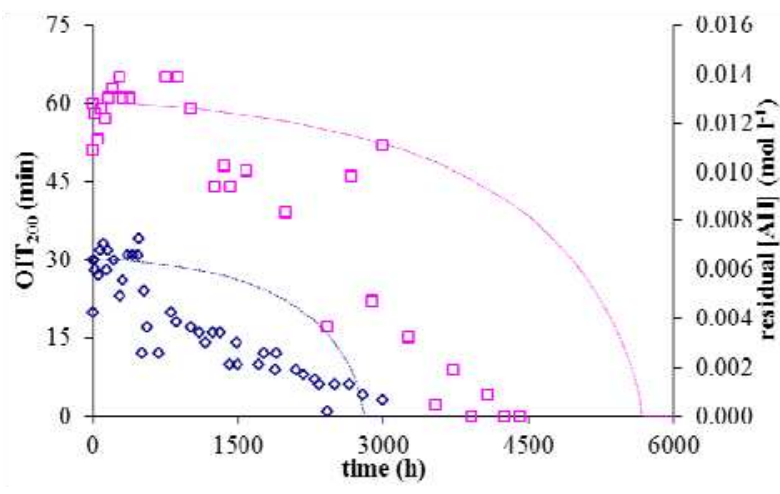

(c)

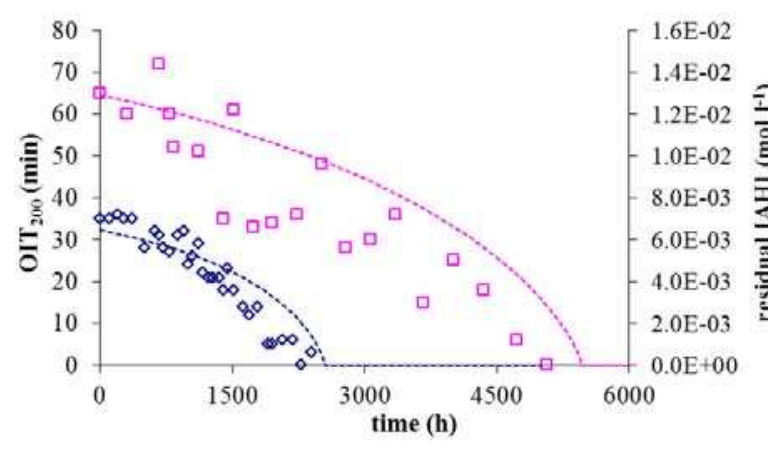

(e)

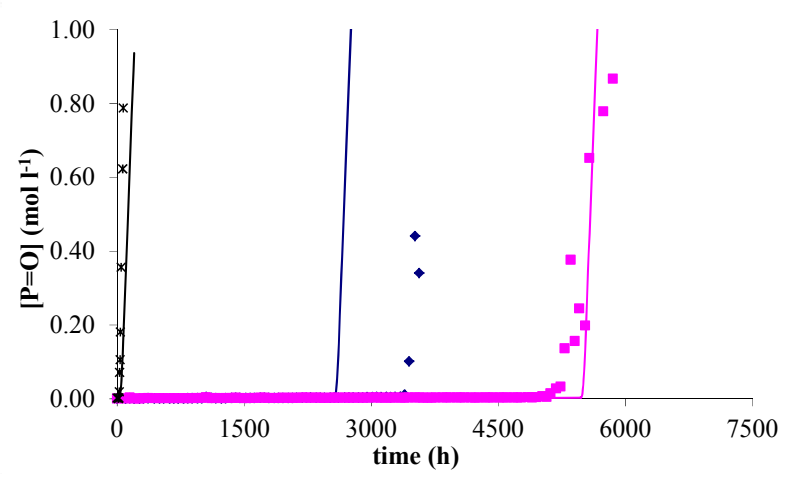

(b)

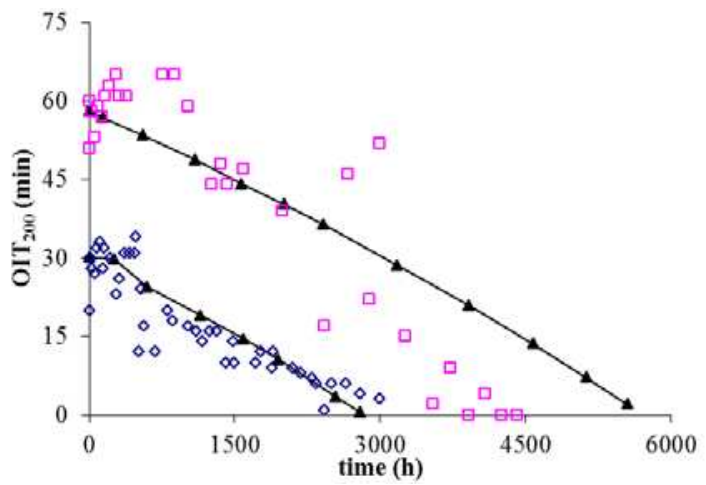

(d)

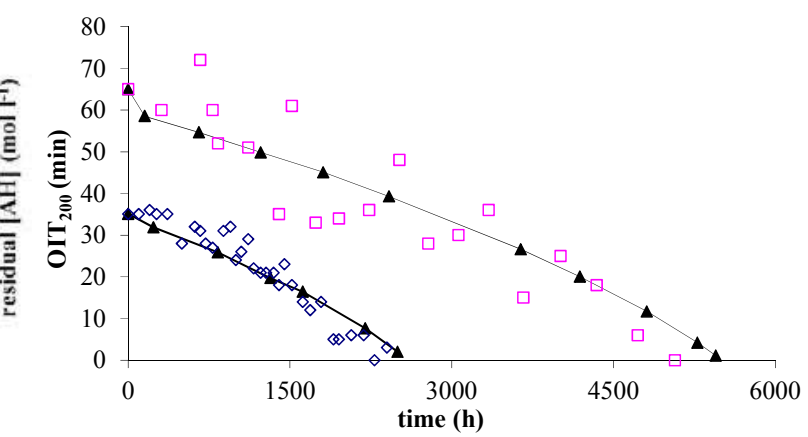

(f)

Figure 6. Simulation of carbonyl build-up at $110^{\circ} \mathrm{C}$ (a) and $120^{\circ} \mathrm{C}$ (b) and comparison of residual $\mathrm{OIT}_{200}$ value at $110^{\circ} \mathrm{C}(\mathrm{c}, \mathrm{e})$ and $120^{\circ} \mathrm{C}(\mathrm{d}, \mathrm{f})$ with $[\mathrm{AH}]$ concentration simulated by model $(\mathrm{c}, \mathrm{e})$ and simulation of $\mathrm{OIT}_{200}(\mathrm{~d}, \mathrm{f})$ using $\mathrm{k}_{\mathrm{S} 1}\left(110^{\circ} \mathrm{C}\right)=4 \times 10^{4}, \mathrm{k}_{\mathrm{S} 1}\left(120^{\circ} \mathrm{C}\right)=3 \times 10^{5} 1$ $\mathrm{mol}^{-1} \mathrm{~s}^{-1}$ and $\mathrm{k}_{\mathrm{S} 2}=5 \times 10^{8} 1 \mathrm{~mol}^{-1} \mathrm{~s}^{-1}$. 
One sees that the fitting is acceptable despite the uncertainties linked to stabilizer repartition in laboratory made samples.

Whatever the temperature, it seems that the condition: $\mathrm{k}_{3}[\mathrm{PH}]<\mathrm{k}_{\mathrm{S} 1}[\mathrm{AH}]$ is fulfilled, which constitutes a rough validation of the physical sense of the rate constants values. The Arrhenius diagram for $\mathrm{k}_{\mathrm{S} 1}$ (Fig. 7) was then built leading to an activation energy ca $80 \mathrm{~kJ} \mathrm{~mol}^{-1}$ consistently with [23].

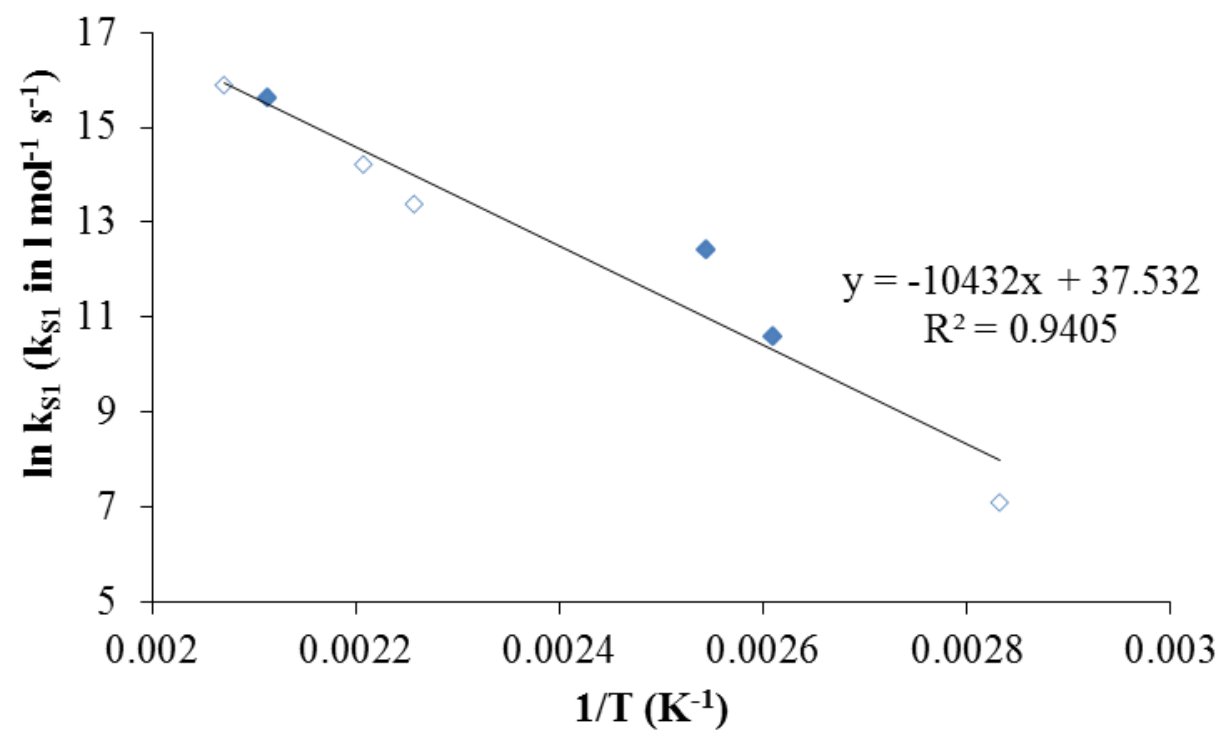

Figure 7. Arrhenius diagram of $\mathrm{k}_{\mathrm{S} 1}(\diamond$ : this work, $\diamond$ : data determined from literature $[34,58,59])$.

The scattering in the Arrhenius plot is not very satisfying, certainly due to several reasons:

- some simplifying hypothesis (such as neglecting the physical effects) in the frame of this comprehensive modelling,

- scattering around the melting temperature: an efficient crystallization process may lead to a change in $[\mathrm{AH}]_{0}$ (see Eq. 1) (or example due to some annealing effects) leading to a possible shift in the $\mathrm{k}_{\mathrm{S} 1}$ value estimated from experimental results. 
In conclusion, despite its simplicity, the proposed model can:

- Simulate the shape of carbonyl build-up curves for PE films stabilized with phenolic antioxidants.

- Simulate the linear increase of induction period with stabilizer concentration, as observed in Fig. 1 and Fig. 2, (in the absence of stabilizer physical loss) using kinetic constants $\mathrm{k}_{\mathrm{S} 1}$ and $\mathrm{k}_{\mathrm{S} 2}$ of which order of magnitude can be justified.

\section{Stabilizers depletion curves in thermal ageing}

It remains to add new criteria of validation. It seemed to us that the simulation of kinetics of antioxidant consumption was a necessary requirement for the model.

Let us first mention that results presented in Fig. 2 and 3 are in our mind very consistent with those reported by Gillen and coll. [60] in their extensive work dealing with the "wear-out" approach, i.e. that the residual OIT/OIT 0 value is a sort of milestone of the conversion process which can be linked to the residual time to end of life $\left(\mathrm{t} / \mathrm{t}_{\mathrm{ind}}\right)$. Here, our aim is to describe the curve of residual stabilizer concentration versus time using our model and try to understand the link between OIT and the residual stabilizer concentration.

The numerical solution of Eq. 7 leads to the theoretical changes of phenol group concentration [AH] (Fig. 6).

Since the concentration in unstable moieties at the beginning of exposure is very low compared to active phenol one, and increases progressively during induction period 
meanwhile phenol group decreases, the accelerated decrease of residual AH group is thus justified.

However, the shape of the residual curve of $\mathrm{OIT}_{200}$ (used as a simple method for detecting active stabilizer) is quite different from the $[\mathrm{AH}]$ changes curve (Fig. 3). It would actually display a pseudo-linear shape as well in this work as in literature [43-46]. Sources of errors in OIT measurements [61] are not in our mind the best explanation for this difference.

Results from literature show that OIT is proportional to stabilizer concentration for a pristine sample [27-37]. In the frame of a modelling approach, it means that OIT is proportional to $[\mathrm{AH}]$ provided that other material parameters $\left(\left[\mathrm{P}^{\circ}\right]_{0},\left[\mathrm{POO}^{\circ}\right]_{0},\left[\mathrm{PO}^{\circ} \mathrm{OP}\right]_{\mathrm{cage} 0}\right.$ and $\left.[\mathrm{POOH}]_{0}\right)$ remain constant.

In the case of materials having undergone a previous oxidation, the positive effect of residual stabilizer concentration on OIT measurements is counterbalanced by the negative influence of alkyl, peroxy, hydroperoxides build-up. It was shown that increasing $[\mathrm{POOH}]_{0}$ results in a significant decrease (and even total loss in extreme cases) of stabilizer efficiency both from a theoretical approach [23] and from experimental measurements [62]. The difference between $[\mathrm{AH}]$ and $\mathrm{OIT}_{200}$ curves (Fig. 3) is hence not surprising.

We have thus implemented the following approach for simulating the $\mathrm{OIT}_{200}$ changes:

(1) Initial state of material is: $\left[\mathrm{P}^{\circ}\right]_{0}=\left[\mathrm{POO}^{\circ}\right]_{0}=\left[\mathrm{PO}^{\circ} \mathrm{OP}\right]_{\text {cage }}=\left[\mathrm{A}^{\circ}\right]_{0}=0,[\mathrm{POOH}]_{0}=10^{-4} \mathrm{~mol}$ $1^{-1},[\mathrm{AH}]_{0}$ from Eq. 1: 
(2) Simulation of oxidation (here for example) at $110^{\circ} \mathrm{C}$ during an exposure time $\left(t_{\text {final }}\right)$ after which polymer was characterized by $\left[\mathrm{P}^{\circ}\right]_{110, \text { tfinal }},\left[\mathrm{POO}^{\circ}\right]_{110, \text { ffinal }}, \quad[\mathrm{POOH}]_{110, \text { tfinal, }}$ $\left[\mathrm{PO}^{\circ \circ} \mathrm{OP}\right]_{\text {cage } 110, \text { tfinal, }}[\mathrm{AH}]_{110, \text { ffinal }}$ and $\left[\mathrm{A}^{\circ}\right]_{110, \text { tfinal }}$ using $\mathrm{k}_{\mathrm{S} 1}=4 \times 10^{4} 1 \mathrm{~mol}^{-1} \mathrm{~s}^{-1}$ at $110^{\circ} \mathrm{C}$ and $\mathrm{k}_{\mathrm{S} 2}$ $=5.10^{8} 1 \mathrm{~mol}^{-1} \mathrm{~s}^{-1}$.

(3) Theoretical calculation of $\mathrm{OIT}_{200}$ value for the oxidized sample by simulating oxidation at $200^{\circ} \mathrm{C}$ under $0.1 \mathrm{MPa} \mathrm{O}_{2}$ with $\mathrm{k}_{\mathrm{S} 1}=6.0 \times 10^{6} 1 \mathrm{~mol}^{-1} \mathrm{~s}^{-1}, \mathrm{k}_{\mathrm{S} 2}=5.10^{8} 1 \mathrm{~mol}^{-1} \mathrm{~s}^{-1}$ and the following initial conditions:

$\left[\mathrm{P}^{\circ}\right]_{200, t=0}=\left[\mathrm{P}^{\circ}\right]_{110, \text { tfinal }} \times\left(1-\mathrm{x}_{\mathrm{C}}\right)$

$\left[\mathrm{POO}^{\circ}\right]_{200, \mathrm{t}=0}=\left[\mathrm{POO}^{\circ}\right]_{110, \text { trinal }} \times\left(1-\mathrm{x}_{\mathrm{C}}\right)$

$[\mathrm{POOH}]_{200, \mathrm{t}=0}=[\mathrm{POOH}]_{110, \text { tfinal }} \times\left(1-\mathrm{x}_{\mathrm{C}}\right)$

$\left[\mathrm{PO}^{\circ \circ} \mathrm{OP}\right]_{\text {cage } 200, \mathrm{t}=0}=\left[\mathrm{PO}^{\circ \circ} \mathrm{OP}\right]_{\text {cage } 110, \text { final }} \times\left(1-\mathrm{x}_{\mathrm{C}}\right)$

$[\mathrm{AH}]_{200, t=0}=[\mathrm{AH}]_{110, \text { final }} \times\left(1-\mathrm{x}_{\mathrm{C}}\right)$,

$\left[\mathrm{A}^{\circ}\right]_{200, \mathrm{t}=0}=\left[\mathrm{A}^{\circ}\right]_{110, \text { final }} \times\left(1-\mathrm{x}_{\mathrm{C}}\right)$

(the factor $1-\mathrm{x}_{\mathrm{C}}$ corresponds to the fact that melting in a semi-crystalline polymer decreases the concentrations in amorphous phase). The $\mathrm{OIT}_{200}$ value was assumed to be equal to the induction period duration of $\mathrm{POOH}$ curve $\mathrm{t}_{\text {ind }}(\mathrm{POOH})$ at $200^{\circ} \mathrm{C}$.

Examples of calculation at $110^{\circ} \mathrm{C}$ are gathered in Table 3. A scheme summarizing the methodology is given in Fig. 8. 


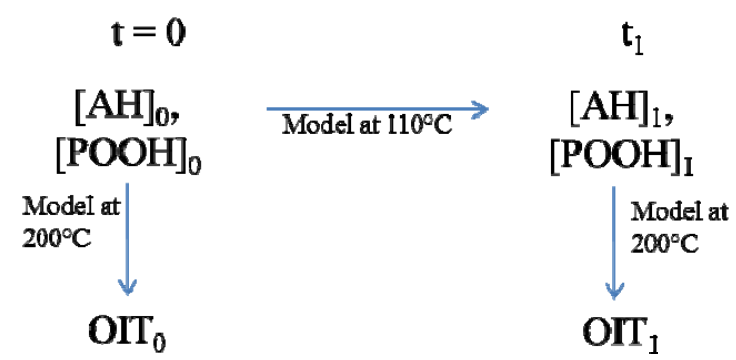

(a)

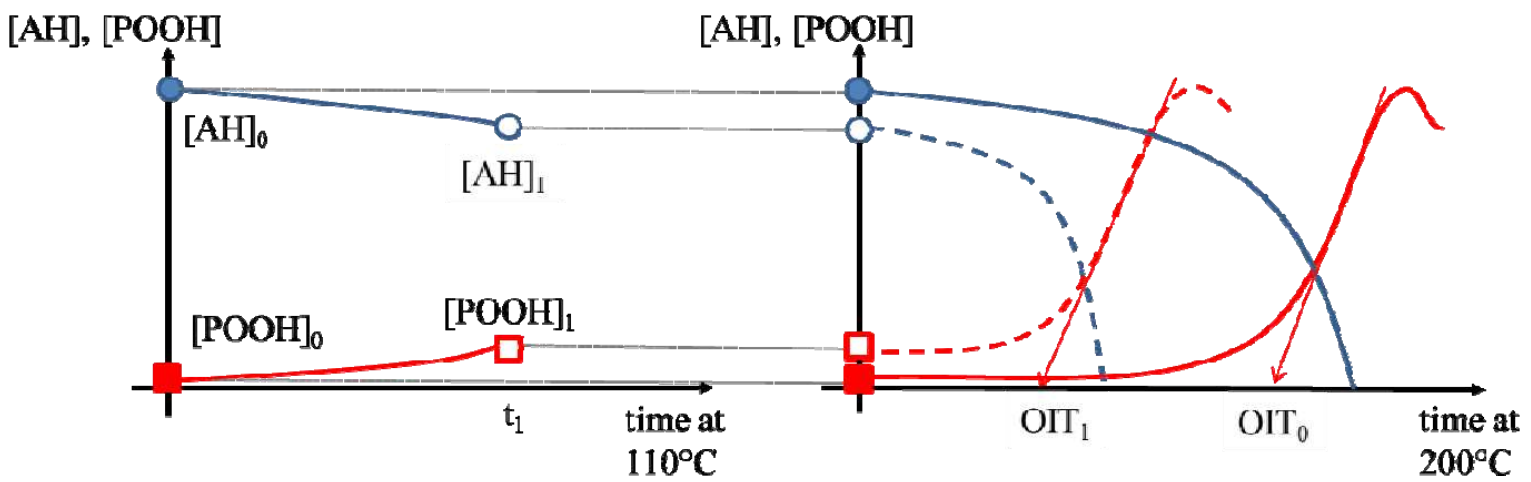

(b)

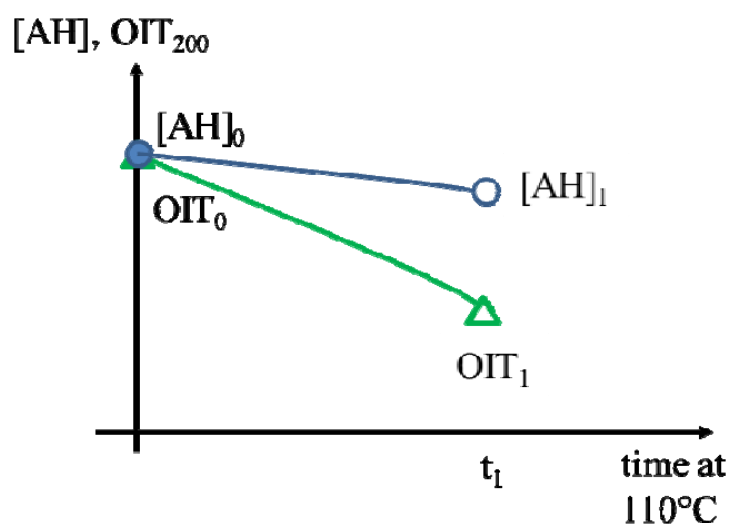

(c)

Figure 8. General method for OIT simulation (a), changes in $\mathrm{POOH}$ and $\mathrm{AH}$ concentration during ageing at $110^{\circ} \mathrm{C}$ and subsequent shape of DSC-OIT curves at $200^{\circ} \mathrm{C} \mathrm{(b)} \mathrm{and} \mathrm{resulting}$ OIT drop versus AH decrease (c). 


\begin{tabular}{|c|c|c|c|c|c|c|}
\hline & \multicolumn{3}{|c|}{$110^{\circ} \mathrm{C}-0.02 \mathrm{MPa} \mathrm{O}_{2}$} & \multicolumn{3}{|c|}{$200^{\circ} \mathrm{C}-0.1 \mathrm{MPa} \mathrm{O}_{2}$} \\
\hline & t (h) & {$[\mathrm{POOH}](\mathrm{t})\left(\mathrm{mol} \mathrm{l}^{-1}\right)$} & {$[\mathrm{AH}](\mathrm{t})\left(\mathrm{mol} \mathrm{l}^{-1}\right)$} & {$[\mathrm{POOH}]_{0}\left(\mathrm{~mol} \mathrm{l}^{-1}\right)$} & {$[\mathrm{AH}]_{0}\left(\mathrm{~mol} \mathrm{l}^{-1}\right)$} & $t_{\text {ind }}($ POOH) (h) \\
\hline \multirow{8}{*}{$0.1 \%$ Irganox 1010} & 0 & $1.0 \mathrm{E}-04$ & $6.5 \mathrm{E}-03$ & $5.0 \mathrm{E}-05$ & $3.2 \mathrm{E}-03$ & $5.0 \mathrm{E}-01$ \\
\hline & 256 & $1.0 \mathrm{E}-04$ & $6.5 \mathrm{E}-03$ & $5.2 \mathrm{E}-05$ & $3.2 \mathrm{E}-03$ & $5.0 \mathrm{E}-01$ \\
\hline & 596 & $1.9 \mathrm{E}-04$ & $6.3 \mathrm{E}-03$ & $9.4 \mathrm{E}-05$ & $3.1 \mathrm{E}-03$ & $4.1 \mathrm{E}-01$ \\
\hline & 1150 & $3.4 \mathrm{E}-04$ & 5.9E-03 & $1.7 \mathrm{E}-04$ & $3.0 \mathrm{E}-03$ & $3.2 \mathrm{E}-01$ \\
\hline & 1590 & $5.7 \mathrm{E}-04$ & $5.5 \mathrm{E}-03$ & $2.8 \mathrm{E}-04$ & 2.7E-03 & $2.4 \mathrm{E}-01$ \\
\hline & 1950 & 8.9E-04 & $4.8 \mathrm{E}-03$ & 4.4E-04 & $2.4 \mathrm{E}-03$ & $1.8 \mathrm{E}-01$ \\
\hline & 2540 & $2.4 \mathrm{E}-03$ & $2.6 \mathrm{E}-03$ & $1.2 \mathrm{E}-03$ & $1.3 \mathrm{E}-03$ & $5.9 \mathrm{E}-02$ \\
\hline & 2800 & $9.0 \mathrm{E}-03$ & $2.3 \mathrm{E}-04$ & $4.5 \mathrm{E}-03$ & $1.2 \mathrm{E}-04$ & 7.0E-03 \\
\hline \multirow{12}{*}{$0.2 \%$ Irganox 1010} & 0 & $1.0 \mathrm{E}-04$ & $1.3 \mathrm{E}-02$ & $5.0 \mathrm{E}-05$ & $6.5 \mathrm{E}-03$ & $9.7 \mathrm{E}-01$ \\
\hline & 147 & $1.1 \mathrm{E}-04$ & $1.3 \mathrm{E}-02$ & $5.5 \mathrm{E}-05$ & $6.5 \mathrm{E}-03$ & $9.5 \mathrm{E}-01$ \\
\hline & 558 & $1.4 \mathrm{E}-04$ & $1.3 \mathrm{E}-02$ & $6.9 \mathrm{E}-05$ & $6.4 \mathrm{E}-03$ & $8.9 \mathrm{E}-01$ \\
\hline & 1090 & $1.8 \mathrm{E}-04$ & $1.3 \mathrm{E}-02$ & $9.0 \mathrm{E}-05$ & $6.3 \mathrm{E}-03$ & $8.1 \mathrm{E}-01$ \\
\hline & 1570 & $2.3 \mathrm{E}-04$ & $1.2 \mathrm{E}-02$ & $1.2 \mathrm{E}-04$ & $6.2 \mathrm{E}-03$ & 7.4E-01 \\
\hline & 2010 & $2.9 \mathrm{E}-04$ & $1.2 \mathrm{E}-02$ & $1.5 \mathrm{E}-04$ & $6.1 \mathrm{E}-03$ & $6.7 \mathrm{E}-01$ \\
\hline & 2410 & $3.6 \mathrm{E}-04$ & $1.2 \mathrm{E}-02$ & $1.8 \mathrm{E}-04$ & $5.9 \mathrm{E}-03$ & $6.1 \mathrm{E}-01$ \\
\hline & 3170 & $5.5 \mathrm{E}-04$ & $1.1 \mathrm{E}-02$ & $2.8 \mathrm{E}-04$ & $5.5 \mathrm{E}-03$ & $4.8 \mathrm{E}-01$ \\
\hline & 3910 & 8.7E-04 & $9.7 \mathrm{E}-03$ & $4.3 \mathrm{E}-04$ & $4.9 \mathrm{E}-03$ & $3.5 \mathrm{E}-01$ \\
\hline & 4580 & $1.4 \mathrm{E}-03$ & 7.9E-03 & 7.0E-04 & $4.0 \mathrm{E}-03$ & $2.3 \mathrm{E}-01$ \\
\hline & 5130 & $2.3 \mathrm{E}-03$ & $5.5 \mathrm{E}-03$ & $1.2 \mathrm{E}-03$ & $2.7 \mathrm{E}-03$ & $1.2 \mathrm{E}-01$ \\
\hline & 5550 & $4.6 \mathrm{E}-03$ & $2.1 \mathrm{E}-03$ & $2.3 \mathrm{E}-03$ & $1.1 \mathrm{E}-03$ & $3.3 \mathrm{E}-02$ \\
\hline
\end{tabular}

Table 3. Simulation of $\mathrm{OIT}_{200}$ value for PE + Irganox 1010 after exposure $110^{\circ} \mathrm{C}$.

In the case of $\mathrm{PE}+0.1 \%$ Irganox 1010 : after $1150 \mathrm{~h}$ of ageing at $110^{\circ} \mathrm{C}$ under air, $[\mathrm{POOH}]$ has increased from $10^{-4}$ to $3.4 \times 10^{-4} \mathrm{~mol}^{-1}$ and $[\mathrm{AH}]$ has decreased from $6.5 \times 10^{-3}$ to $5.9 \times 10^{-3}$ mol $1^{-1}$. Corresponding $\mathrm{OIT}_{200}$ of this sample (i.e. the $\mathrm{POOH}$ induction time at $200^{\circ} \mathrm{C}$ under $0.1 \mathrm{MPa} \mathrm{O}_{2}$ with the initial boundary conditions: $[\mathrm{POOH}]_{0}=3.4 \times 10^{-4} / 2 \mathrm{~mol} \mathrm{l}^{-1}$ and $[\mathrm{AH}]_{0}=$ $5.9 \times 10^{-3} / 2 \mathrm{~mol}^{-1}$ ) is equal to $19 \mathrm{~min}$ for the aged sample instead of 30 for the virgin one (See also Fig. 8).

$\mathrm{OIT}_{200}$ simulations (Fig. 6) are in better agreement with experimental results than simulation of residual $[\mathrm{AH}]$ concentration after $110^{\circ} \mathrm{C}$ and $120^{\circ} \mathrm{C}$ exposure. Let us mention that $\mathrm{OIT}_{200}$ is unchanged if the initial conditions for exposure at $200^{\circ} \mathrm{C}$ are: $\left[\mathrm{P}^{\circ}\right]_{200, t=0}=\left[\mathrm{POO}^{\circ}\right]_{200, t=0}=$ $\left[\mathrm{PO}^{\circ} \mathrm{OP}\right]_{\text {cage } 200, \mathrm{t}=0}=\left[\mathrm{A}^{\circ}\right]_{200, \mathrm{t}=0}=0$. This is in good agreement with previous observations on the model sensitivity to boundary conditions [54]: hydroperoxides are actually the key species of our model and their initial concentration controls the overall oxidation kinetics meanwhile radicals concentration plays a secondary role. 
According to Gugumus [63], a critical interpretation of a comprehensive set of data obtained with PP and LDPE showed explicitly that samples of stabilized polyolefins may fail even if there is still a rather high concentration of antioxidant. According to Pospíšil [64], these observations stimulated the formulation of a new concept called "critical concentration level" defined as the degree of oxidation of the polymer beyond which the stabilizing system is no longer available to cope with the considerably enhanced oxidation rate induced by the oxidation products that have accumulated. Here, the model verifies this scenario.

It has the following consequences:

- $\mathrm{OIT}_{200}$ can not be used for quantifying residual stabilizer after ageing if the concentration in POOH generated by ageing is not measured.

- The model can simulate complex ageing cases, for example an exposure at $110^{\circ} \mathrm{C}$ or $120^{\circ} \mathrm{C}$ followed by another one at $200^{\circ} \mathrm{C}$. The principle is to use the final $[\mathrm{POOH}]$ and $[\mathrm{AH}]$ value of an ageing cycle as the initial conditions for the next one.

\section{Some comments on the possible heterogeneity in oxidation of stabilized polyolefins}

According to George and Verdu [24], heterogeneity in stabilizer polymer oxidation could originate in an heterogeneous stabilizer spatial repartition. It seemed to us interesting to compare this scenario with model prediction. To that purpose, we did three simulation runs differing by their initial conditions: $[\mathrm{POOH}]_{0}$ and $[\mathrm{AH}]_{0}$ (Fig. 9):

- a first one with $[\mathrm{POOH}]_{0}=10^{-4} \mathrm{~mol} \mathrm{l}^{-1},[\mathrm{AH}]_{0}=0.005 \mathrm{~mol} \mathrm{l}^{-1}$ representing an average sample, 
- a second one with $[\mathrm{POOH}]_{0}=10^{-4} \mathrm{~mol} \mathrm{l}^{-1},[\mathrm{AH}]_{0}=0.0045 \mathrm{~mol} \mathrm{l}^{-1}$ representing the same sample with a little local heterogeneity in initial stabilizer concentration, induced, for example by processing,

- a third one with $[\mathrm{POOH}]_{0}=10^{-3} \mathrm{~mol} \mathrm{l}^{-1},[\mathrm{AH}]_{0}=0.005 \mathrm{~mol} \mathrm{l}^{-1}$ representing a part of the sample which would be 'polluted' by a moiety likely to initiate oxidation (typically a metallic particle coming from catalyst residue, processing or sampling).

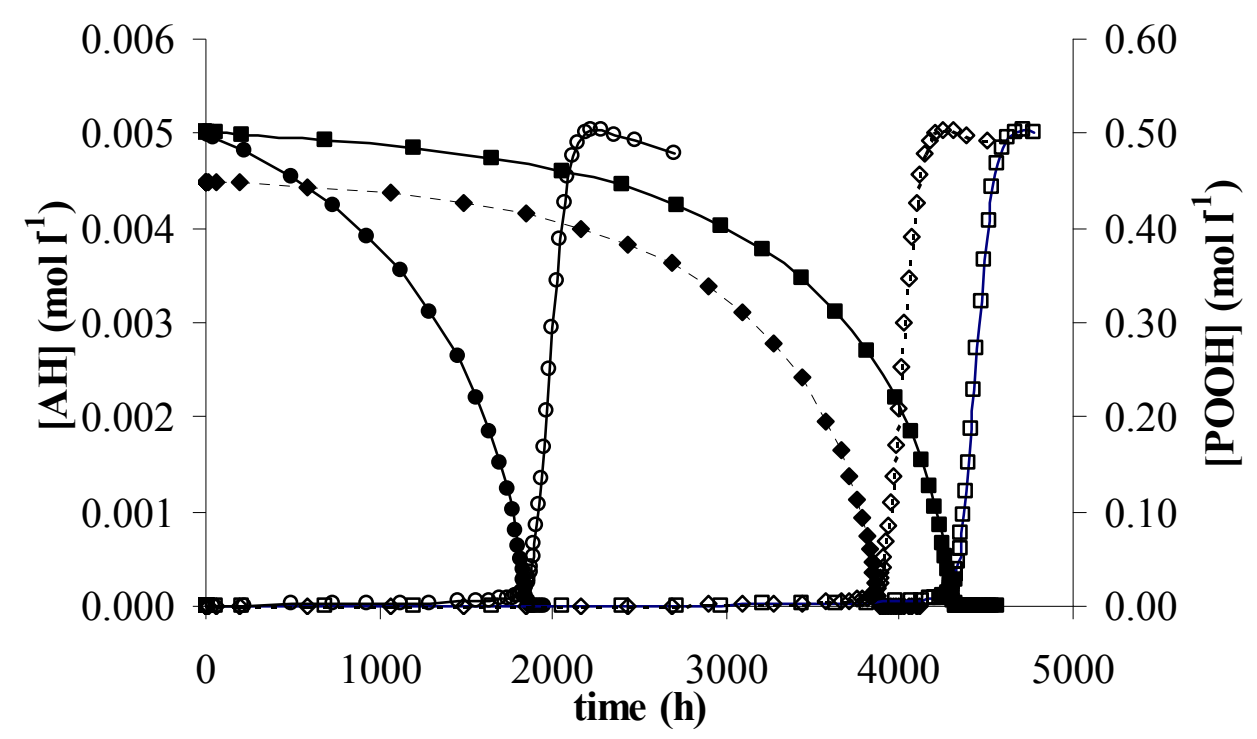

Figure 9. Simulation runs for $\mathrm{T}=110^{\circ} \mathrm{C}$ with $\mathrm{k}_{\mathrm{S} 1}=5 \times 10^{4} 1 \mathrm{~mol}^{-1} \mathrm{~s}^{-1}, \mathrm{k}_{\mathrm{S} 2}=5.10^{8} 1 \mathrm{~mol}^{-1}$ and PE rate constants from Table 1.

(1) $[\mathrm{AH}](\mathbf{\square})$ and $[\mathrm{POOH}](\square)$ with $[\mathrm{POOH}]_{0}=10^{-4} \mathrm{~mol} \mathrm{l}^{-1},[\mathrm{AH}]_{0}=0.005 \mathrm{~mol} \mathrm{l}^{-1}$

(2) $[\mathrm{AH}](\diamond)$ and $[\mathrm{POOH}](\diamond)$ with $[\mathrm{POOH}]_{0}=10^{-4} \mathrm{~mol} \mathrm{l}^{-1},[\mathrm{AH}]_{0}=0.0045 \mathrm{~mol} \mathrm{l}^{-1}$

(3) $[\mathrm{AH}](\bigcirc)$ and $[\mathrm{POOH}](\mathrm{O})$ with $[\mathrm{POOH}]_{0}=10^{-3} \mathrm{~mol} \mathrm{l}^{-1},[\mathrm{AH}]_{0}=0.005 \mathrm{~mol} \mathrm{l}^{-1}$

According to simulations (1) and (2), the model predicts that even a slight difference in stabilizer concentration induces a strong difference around the induction in oxidation level (here expressed by $[\mathrm{POOH}]$ ) due to the intrinsic auto-accelerated behaviour of oxidation period : sample (1) is reaching the end of induction period at ca $4300 \mathrm{~h}$ meanwhile sample (2) 
is reaching maximal $\mathrm{POOH}$ concentration i.e. oxidation steady state. In other words, the model simulations are consistent with the scenario proposed by [24].

The comparison of simulations (1) and (3) shows that the model simulates the fact that the polluted part of polymer oxidizes much faster than non-polluted one. It would correspond to the observations by Gijsman and coll [25] according to which a film of polymer oxidizes faster at its edges than in the middle (having in mind that such films are generally cut using metallic tools). In conclusion, it shows that this model could be a heuristic tool for a better understanding of the heterogeneity in oxidation of stabilized polyolefins. 


\section{CONCLUSION}

The oxidation kinetics of polyethylene stabilized by Irganox 1010 have been simulated using a model starting from the previously established scheme for unstabilized PE to which two stabilizing elementary reactions $\mathrm{S} 1$ and $\mathrm{S} 2$ were added. S1 is the classical reaction of the stabilizer with a peroxy radical $\mathrm{POO}^{\circ}$ giving a hydroperoxide and a phenoxy radical $\mathrm{A}^{\circ}$. S2 is the terminating combination of $\mathrm{POO}^{\circ}$ with $\mathrm{A}^{\circ}$. Rate constants for stabilizer chemical consumption were determined. Even though they are not the optimal set, they constitute at least an approached solution for future studies including more complex cases of stabilization coupled with physical loss. Model simulates the shape of carbonyl build up, linear dependence of induction period with stabilizer concentration. This model simulates also the kinetic of residual OIT depletion in thermal ageing. An implication of this work is that OIT can actually be used for quantifying polyolefins in a virgin grade of a given polymer (for some manufacturing quality concerns) but not in an oxidized polymer. 


\section{REFERENCES}

1. Schwarzenbach K, Gilg B, Muller D, Knobloch G, Pauquet JR, Rota-Graziosi P, Schmitter A, Zingg J. In: Zweifel H, editor. Plastics Additives Handbook, 5th ed. Cincinnati: Hanser Gardner Publications, 2001. p. 1.

2. Ritter A, Michel E, Schmid M, Affolter S. Interlaboratory test on polymers: determination of antioxidants in polyolefins. Polym Test 2005;24(4):498-506.

3. Bataillard P, Thomas M. In: Zweifel H, editor. Plastics Additives Handbook, 5th ed. Cincinnati: Hanser Gardner Publications, 2001. p. 1047.

4. Strandberg C, Burman L, Albertsson A-C. Total luminescence intensity (TLI) offers superior early oxidation detection in unstabilised polyethylene but is no better than FT-IR for stabilised polyolefins. Eur Polym J 2006;42(2):1855-1865.

5. Lundbäck M, Strandberg C, Albertsson A-C, Hedenqvist MS, Gedde UW. Loss of stability by migration and chemical reaction of Santonox ${ }^{\circledR}$ in branched polyethylene under anaerobic and aerobic conditions. Polym Degrad Stab 2006;91(5):1071-1078.

6. Azhdar B, Yu W, Reitberger T, Gedde UW. A new method for assessing the efficiency of stabilizers in polyolefins exposed to chlorinated water media. Polym Test 2009;28(6):661667.

7. Billingham NC. In: Zweifel H, editor. Plastics Additives Handbook, 5th ed. Cincinnati: Hanser Gardner Publications, 2001. p. 1019.

8. Calvert PD, Billingham NC. Loss of additives from polymers: A theoretical model. J Appl Polym Sci 1979;24(2):357-370.

9. Billingham NC, Calvert PD, Okopi IW, Uzuner A. The solubility of stabilizing additives in polypropylene. Polym Degrad Stab 1991;31(1):23-36.

10. Billingham NC, Calvert PD, Manke AS. Solubility of phenolic antioxidants in polyolefins. J Appl Polym Sci 1981;26(11):3543-3555.

11. Roe R.-J., Bair H.E., Gieniewski C. Solubility and diffusion coefficient of antioxidants in polyolefins. J Appl Polym Sci 1974;18(3):843-856.

12. Malík, J., Hrivík, A., Tuan, D.Q. Diffusion and solubility of hindered amine light stabilizers in polyolefins: Influence on stabilization efficiency and implications for polymerbound stabilizers. Advances in Chemistry Series 1996;249:452-453.

13. Richaud E, Monchy-Leroy C, Colin X, Audouin L, Verdu J. Kinetic modelling of stabilization coupled with stabilizer loss by evaporation. Case of dithioester stabilized polyethylene. Polym Degrad Stab 2009;94(11):2004-2014.

14. Djouani F, Richaud E, Fayolle B, Verdu J. Modelling of thermal oxidation of phosphite stabilized polyethylene. Polym Degrad Stab 2011;96(7):1349-1360. 
15. Lundbäck M, Hedenqvist MS, Mattozzi A, Gedde UW. Migration of phenolic antioxidants from linear and branched polyethylene. Polym Degrad Stab 2006;91(7):15711580 .

16. Földes E, Turcsányi B. Transport of small molecules in polyolefins. I. Diffusion of irganox 1010 in polyethylene. J Appl Polym Sci 1992;46(3):507-515.

17. Földes E. Transport of small molecules in polyolefins. II. Diffusion and solubility of irganox 1076 in ethylene polymers. J Appl Polym Sci 1993;48(11):1905-1913.

18. Földes E. Transport of small molecules in polyolefins, III. diffusion of Topanol CA in ethylene polymers. J Appl Polym Sci 51(9), p. 1581-1589 (1994).

19. Limm W, Hollifield HC. Modelling of additive diffusion in polyolefins. Food Add Contam 1996;13(8):949-967.

20. Durgis J, Karvaš M, Čaučik P, Holčik J. Loss of light stabilizers from polypropylene. Eur Polym J 1975;11(3):219-222.

21. Serna LV, Becker JL, Galdámez, JR, Danner, R.P., Duda, J.L. Elastic effects on solubility in semicrystalline polymers. J Appl Polym Sci 2008;107(1):138-146.

22. Billingham NC. Designing polymer additives to minimise loss. Makromolekulare Chemie. Macromolecular Symposia 1989;27(1):187-205.

23. Richaud E, Fayolle B, Verdu J. Polypropylene stabilization by hindered phenols - Kinetic aspects. Polym Degrad Stab 2011;96(1):1-11.

24. Fayolle B, Audouin L, George GA, Verdu J. Macroscopic heterogeneity in stabilized polypropylene thermal oxidation. Polym Degrad Stab 2002;77(3):515-522.

25. Hamskog M, Terselius B, Gijsman P. Multi-cell imaging chemiluminescence to map heterogeneous degradation of polypropylene plaques. Polym Degrad Stab 2003;82(2):181186.

26. Rugg FM, Smith JJ, Bacon RC. Infrared spectrophotometric studies on polyethylene. II. Oxidation. J Polym Sci 1954;13(72):535-547.

27. Pospíšil J, Horák Z, Pilař J, Billingham NC, Zweifel H, Nešpůrek S. Influence of testing conditions on the performance and durability of polymer stabilisers in thermal oxidation. Polym Degrad Stab 2003;82(2):145-162.

28. Klemchuk PP, Horng P-L. Perspectives on the stabilization of hydrocarbon polymers against thermo-oxidative degradation. Polym Degrad Stab 1984;7(3):131-151.

29. Chirinos-Padrón AJ, Hernández PH, Allen NS, Vasilion C, Marshall GP, de Poortere M. Synergism of antioxidants in high density polyethylene. Polym Degrad Stab 1987;19(2):177189. 
30. Peña JM, Allen NS, Edge M, Liauw CM, Valange B. Interactions between carbon black and stabilisers in LDPE thermal oxidation. Polym Degrad Stab 2001;72(1):163-174.

31. Jipa S, Osawa Z, Otsuki H, Nishimoto M. Chemiluminescence assessment of the effectiveness of some phenolic antioxidants for heat stabilization of irradiated LDPE. Polym Degrad Stab 1997;56(1):45-53.

32. Jipa S, Zaharescu T, Gorghiu LM, Dumitrescu C, Gigante B, Esteves MA, Brites MJS. LDPE protected by secondary amines of dehydroabietic methyl ester derivatives. Polym Test 2004;23(8):911-917.

33. Jipa S, Zaharescu T, Oros C, Gorghiu LM, Setnescu R, Dumitrescu C, Olteanu RL. LDPE degradation by IR-laser irradiation. Polym Test 2005;24(6):805-809.

34. Latocha C, Uhniat M. Usability analysis of a simplified kinetic equation for evaluation of antioxidant action in LDPE. Polym Degrad Stab 1992;35(2):115-120.

35. Lundbäck M, Hedenqvist MS, Mattozzi A, Gedde UW. Migration of phenolic antioxidants from linear and branched polyethylene. Polym Degrad Stab 2006;91(7):15711580 .

36. Øgaard Madsen J, Berg Olsen N, Atlung G. Effectiveness of antioxidants: Suppression of evolution of gaseous degradation products from low-density polyethylene during thermooxidation. Polym Degrad Stab 1985;12(2):131-140.

37. Uhniat M, Kudła S. Stabilisation of LDPE cross-linked in the presence of peroxides I. Kinetic study of the oxidation. Polym Degrad Stab 2000;71(1):69-74.

38. Pospíšil J, Habicher W-D, Pilař J, Nešpůrek S, Kuthan J, Piringer G-O, Zweifel H. Discoloration of polymers by phenolic antioxidants. Polym Degrad Stab 2002;77(3):531-538.

39. Taimr L, Pospíšil J. Antioxidants and stabilizers: Part XCV-A co-operative effect between antioxidants N-iso-propyl-N'-phenyl-1,4-phenylene diamine and 2,6-di-tertbutylphenol. Polym Degrad Stab 1984;8(1):23-35.

40. Zeynalov EB, Allen NS. Modelling light stabilizers as thermal antioxidants. Polym Degrad Stab 2006;91(12):3390-3396.

41. Sedlář J, Petrúj J, Pác J, Zahradníčková A. Photostabilizing activity of sterically hindered piperidines-II: Radical trapping. Eur Polym J 1980;16(7):663-669.

42. Richaud E, Colin X, Monchy-Leroy C, Audouin L, Verdu J. Polyethylene stabilization against thermal oxidation by a trimethylquinoleine oligomer. Polym Degrad Stab 2009;94(3):410-420.

43. Kramer E, Koppelmann J. Measurement of oxidation stability of polyolefins by thermal analysis. Polym Degrad Stab 1986;16(3):261-275. 
44. Cramez MC, Oliveira MJ, Crawford RJ. Optimisation of rotational moulding of polyethylene by predicting antioxidant consumption. Polym Degrad Stab 2002;75(2):321-327.

45. Weon J-I. Effects of thermal ageing on mechanical and thermal behaviors of linear low density polyethylene pipe. Polym Degrad Stab 2010;95(1):14-20.

46. Moore LM, Marshall GP, Allen NS. Thermal analysis of MDPE pipe: A critical view. Polym Degrad Stab 1989;25(2-4):161-180.

47. Mueller W, Jakob I. Oxidative resistance of high-density polyethylene geomembranes. Polym Degrad Stab 2003;79(1):161-172.

48. Allen NS, Chirinis-Padron A, Henman TJ. The photo-stabilisation of polypropylene: A review. Polym Degrad Stab 1985;13(1):31-76.

49. Pospíšil J. The key role of antioxidant transformation products in the stabilization mechanisms - A critical analysis. Polym Degrad Stab 1991;34(1-3):85-109.

50. Pospíšil J. Chemical and photochemical behaviour of phenolic antioxidants in polymer stabilization: A state of the art report, part II. Polym Degrad Stab 1993;39(1):103-115.

51. Khelidj N, Colin X, Audouin L, Verdu J, Monchy-Leroy C, Prunier V. Oxidation of polyethylene under irradiation at low temperature and low dose rate. Part II. Low temperature thermal oxidation. Polym Degrad Stab 2006;91(7):1598-1605.

52. Denisov ET, Afanas'ev IB. Oxidation and Antioxidants in Organic Chemistry and Biology. Boca Raton, London, New York, Singapore: CBC Taylor \& Francis Group, 2005. p. 510 .

53. Colin X, Monchy-Leroy C, Audouin L, Verdu J. Lifetime prediction of polyethylene in nuclear plants. Nucl Instrum Meth B 2007;265(1):251-255.

54. Colin X, Fayolle B, Audouin L, Verdu J. About a quasi-universal character of unstabilised polyethylene thermal oxidation kinetics. Polym Degrad Stab 2003;80(1):67-74.

55. Richaud E, Colin X, Fayolle B, Audouin L, Verdu J. Induction period in the lowtemperature thermal oxidation of saturated hydrocarbons: Example of polyethylene. Int $\mathrm{J}$ Chem Kin 2008;40(12):769-777.

56. Van Krevelen DW, Te Nijenhuis K. Properties of polymers, their correlation with chemical structure; their numerical estimation and prediction from additive group contributions, 4th Edition. Amsterdam: Elsevier, 2009.

57. Ouldmetidji Y, Gonon L, Commereuc S, Verney V. A differential scanning calorimetry method to study polymer photoperoxidation. Polym Test 2001;20(7):765-768.

58. Setnescu T, Jipa S, Setnescu R, Mihalcea I. Synergistic effects of some phenolic inhibitors used in polyethylene stabilization-II. Oxyluminescence method for studying the synergistic effects of some binary mixtures of phenolic stabilizers. Polym Degrad Stab 1996;52(1):19-23. 
59. Mallégol J, Carlsson DJ, Deschênes L. A comparison of phenolic antioxidant performance in HDPE at 32-80 C. Polym Degrad Stab 2001;73(2):259-267.

60. Gillen KT, Celina M, Bernstein R, Shedd M. Lifetime predictions of EPR materials using the Wear-out approach. Polym Degrad Stab 2006;91(12):3197-3207.

61. Rosa DS, Sarti J, Mei LHI, Filho MM, Silveira S. A study of parameters interfering in oxidative induction time (OIT) results obtained by differential scanning calorimetry in polyolefin. Polym Test 2000;19(5):523-531.

62. Allen NS, Marshall GP, Vasiliou C, Moore LM, Kotecha JL, Gardette J-L, Valange B. Oxidation processes in blue water pipe. Polym Degrad Stab 1988;20(3-4):315-324.

63. Gugumus F. Aspects of the stabilization mechanisms of phenolic antioxidants in polyolefins. Angew Makrom Chem 1985;137(1):189-225.

64. Pospíšil J. Mechanistic action of phenolic antioxidants in polymers-A review. Polym Degrad Stab 1988;20(3-4):181-202. 